\title{
Deletion of Wiskott-Aldrich syndrome protein triggers Rac2 activity and increased cross-presentation by dendritic cells
}

\author{
Marisa A.P. Baptista1,2, Marton Keszei ${ }^{1}$, Mariana Oliveira1, Karen K.S. Sunahara ${ }^{1,3}$, John Andersson ${ }^{4}$, \\ Carin I.M. Dahlberg ${ }^{1}$, Austen J. Worth ${ }^{5}$, Agne Liedén ${ }^{6}$, I-Chun Kuo ${ }^{7,8}$, Robert P.A. Wallin', Scott B. Snapper ${ }^{9}$, \\ Liv Eidsmo $^{10}$, Annika Scheyniuss ${ }^{4}$, Mikael C.I. Karlsson1, Gerben Bouma ${ }^{5}$, Siobhan O. Burns 5,11,12, \\ Mattias N.E. Forsell ${ }^{1,13}$, Adrian J. Thrasher ${ }^{5}$, Susanne Nylén ${ }^{1} \&$ Lisa S. Westerberg ${ }^{1}$
}

Wiskott-Aldrich syndrome (WAS) is caused by loss-of-function mutations in the WASp gene. Decreased cellular responses in WASp-deficient cells have been interpreted to mean that WASp directly regulates these responses in WASp-sufficient cells. Here, we identify an exception to this concept and show that WASp-deficient dendritic cells have increased activation of Rac2 that support cross-presentation to $\mathrm{CD}^{+}{ }^{+} \mathrm{T}$ cells. Using two different skin pathology models, WASp-deficient mice show an accumulation of dendritic cells in the skin and increased expansion of IFN $\gamma$-producing $\mathrm{CD} 8^{+} \mathrm{T}$ cells in the draining lymph node and spleen. Specific deletion of WASp in dendritic cells leads to marked expansion of CD8 ${ }^{+}$ $\mathrm{T}$ cells at the expense of $\mathrm{CD} 4{ }^{+} \mathrm{T}$ cells. WASp-deficient dendritic cells induce increased cross-presentation to $\mathrm{CD} 8{ }^{+} \mathrm{T}$ cells by activating Rac2 that maintains a near neutral $\mathrm{pH}$ of phagosomes. Our data reveals an intricate balance between activation of WASp and Rac2 signalling pathways in dendritic cells.

\footnotetext{
${ }^{1}$ Department of Microbiology Tumor and Cell biology, Karolinska Institutet, Stockholm 171 77, Sweden. ${ }^{2}$ Institute for Virology and Immunobiology, University of Würzburg, 97078 Würzburg, Germany. ${ }^{3}$ Experimental Physiopathology, Department of Sciences/Experimental Physiopatholgy, Medical School, University of São Paulo, São Paulo, Brazil. ${ }^{4}$ Department of Medicine Solna, Translational Immunology Unit, Karolinska Institutet and Karolinska University Hospital, Stockholm 171 76, Sweden. ${ }^{5}$ University College London Institute of Child Health, London WC1N 1EH, UK. ${ }^{6}$ Department of Molecular Medicine and Surgery, Karolinska Institutet, Stockholm 171 76, Sweden. ${ }^{7}$ Department of Paediatrics, Yong Loo Lin School of Medicine, National University of Singapore, Singapore 119228, Singapore. ${ }^{8}$ Khoo Teck Puat-National University Children's Medical Institute, The National University Health System, Singapore 119228, Singapore. ${ }^{9}$ Gastroenterology Division, Children's Hospital, Harvard Medical School, Boston MA 02115, USA. ${ }^{10}$ Department of Medicine Solna, Dermatology and Venereology Unit, Karolinska Institutet, Stockholm 171 76, Sweden. ${ }^{11}$ Department of Immunology, Royal Free London NHS Foundation Trust, London NW3 2QG, UK. ${ }^{12}$ University College London Institute of Immunity and Transplantation, London WC1E 6BT, UK. ${ }^{13}$ Department of Clinical Microbiology, Division of Immunology, Umeå University, Umeå 901 87, Sweden. Correspondence and requests for materials should be addressed to L.S.W. (email: Lisa.Westerberg@ki.se).
} 
W iskott-Aldrich syndrome (WAS) is a severe X-linked primary immunodeficiency caused by loss-of-function mutations in the gene encoding the WAS protein (WASp) $^{1-3}$. More than $80 \%$ of WAS patients develop skin rash characterized as atopic eczema during infancy and childhood ${ }^{1-4}$. One possible reason for development of skin rash is the reduced function of WASp-deficient regulatory $\mathrm{T}$ cells that have poor suppressive activity in vitro and in vivo ${ }^{5-8}$. Surprisingly in the context of eczema, WASp-deficient mast cells have decreased capacity to degranulate upon triggering of the FcER1 (ref. 9). WASp-deficient Langerhans cells have decreased emigration from the epidermis upon activation with hapten ${ }^{10}$, and it has been suggested that skin pathology in WAS may be caused by local accumulation of dendritic cells (DCs) in the skin ${ }^{1,10-13}$.

WASp belongs to the WASp family of proteins also including neuronal (N)-WASp and WASp-family verprolin-homologous protein (WAVE)/suppressor of the cyclic AMP receptor (SCAR) $1-3$, and they together coordinate receptor signalling to changes in the actin cytoskeleton ${ }^{1-3}$. At rest, WASp and N-WASp resides in an auto-inhibited conformation. Upon binding of the small Rho GTPase Cdc42, the auto-inhibited conformation is released and exposes the carboxy-terminal verprolin-cofilin-acidic (VCA) domain that allows for recruitment of the Arp2/3 complex and actin polymerization ${ }^{14,15}$. The small Rho GTPases Rac1 and Rac2 regulate activation of the WAVE/Scar proteins to stimulate actin polymerization by the VCA domain ${ }^{16,17}$.

Langerhans cells and $\mathrm{CD} 103^{+}$DCs in the skin, and CD8 ${ }^{+}$DCs and to a lesser extent $\mathrm{CD} 8^{-}$DCs in the draining lymph nodes (dLNs) and spleen possess a unique capacity for presenting exogenous antigen on major histocompatibility (MHC) class I in a process termed cross-presentation ${ }^{18-20}$. The superior capacity of specific DCs to cross-present antigens results from that DCs in contrast to other phagocytic cells can maintain a near neutral $\mathrm{pH}$ in phagocytic and endocytic vesicles ${ }^{20}$. Rac2 is a key component for cross-presentation of soluble antigens and localize to intracellular membranes in which Rac2 regulates the NADPH complex, thereby maintaining a near neutral $\mathrm{pH}$ in phagosomes and endosomes ${ }^{21}$. Moreover, $\mathrm{CD} 88^{-}$DCs can take up antigen in the form of immune complex by $\mathrm{Fc}$ receptors and efficiently shuttle exogenous antigens efficiently into the cross-presentation pathway ${ }^{22-24}$. The role of WASp in cross-presentation has been investigated by direct targeting of antigen to the DEC205 receptor expressed on CD8 ${ }^{+}$ $\mathrm{DCs}^{13}$. WASp KO CD8 ${ }^{+}$DCs induced shorter contact duration with wild-type $\mathrm{CD} 8{ }^{+} \mathrm{T}$ cells in vivo leading to decreased early activation of $\mathrm{CD}^{+}{ }^{+} \mathrm{T}$ cells ${ }^{13}$. In the specific anti-viral response, WASp KO mice have decreased capacity to mount an antigenspecific $\mathrm{CD}^{+}{ }^{+} \mathrm{T}$ cell response to lymphocytic choriomeningitis virus (LCMV) infection ${ }^{25}$ and influenza ${ }^{26,27}$.

Here, we examined the response of WASp KO mice to skin challenge. Our findings show that WASp KO mice can respond to allergens and parasite infiltration in the skin. However, the immune response is skewed to DC-mediated activation of $\mathrm{CD} 8^{+}$ $\mathrm{T}$ cells that produce IFN $\gamma$. We provide evidence for that WASp $\mathrm{KO} \mathrm{CD}^{-}{ }^{-}$DCs upregulate the molecular machinery to crosspresent antigens and activate $\mathrm{CD} 8^{+} \mathrm{T}$ cells. Our data suggests that downregulation of cross-presentation by WASp may be an active process that is essential to prevent over-activation of $\mathrm{CD} 8{ }^{+} \mathrm{T}$ cells.

\section{Results}

Der $\mathbf{p} 2$ induces skin pathology in WASp KO mice. To induce an eczema-like phenotype, mice were shaved and treated by epicutaneous patching on the back skin with Der p 2, a major allergen from the house dust mite Dermatophagoides pteronyssinus ${ }^{28}$. Since the shaving in itself mimics mechanical injury inflicted by scratching of dry itchy skin in human eczema, we compared shaved mice patched with Der p 2 to that of unshaved unchallenged mice. To examine skin pathology at day 50 , a $4 \mathrm{~mm}^{2}$ punch biopsy was taken from macroscopically inflamed back skin. Epidermal thickening is a hallmark of atopic dermatitis and wild-type mice showed, after three patches with Der p 2, epidermal hyperplasia (Fig. 1a) ${ }^{29,30}$ with increased number of $\mathrm{Ki}^{+}{ }^{+}$proliferating epidermal keratinocytes (Supplementary Fig. 1a). Der p 2-challenged WASp KO mice showed less epidermal hyperplasia (Fig. 1a; Supplementary Fig. 1a). We prepared epidermal sheets and found that Langerhans cells in both wild-type mice and WASp KO mice were decreased in epidermis after Der p 2 challenge (Fig. 1b). To identify dermal DCs and Langerhans cells, we quantified the number of DC subsets in dermis including $\mathrm{CD}_{11 \mathrm{c}^{+}} \mathrm{EpCAM}^{+}$ (epithelial cell adhesion molecule), Langerin $^{+}$and

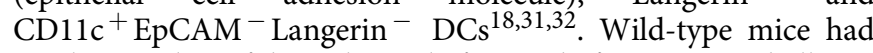
similar number of dermal DCs before and after Der $\mathrm{p} 2$ challenge (Fig. 1c; Supplementary Fig. 1b), suggesting that the marked reduction of epidermal Langerhans cells after Der $\mathrm{p} 2$ challenge in wild-type mice is caused by egress of Langerhans cells from the skin to the dLNs. Unchallenged WASp KO mice had decreased number of dermal Langerin ${ }^{+}$DCs (Fig. 1c), while after Der p 2 challenge WASp KO mice had increased number of $\mathrm{CD}_{11 c^{+}} \mathrm{EpCAM}^{+}$, Langerin $^{+}$and $\mathrm{CD}_{11 c^{+}} \mathrm{EpCAM}^{-}$Langerin $^{-}$ DCs in the dermis (Fig. 1c; Supplementary Fig. 1b). We detected similar number of $\mathrm{Ki}^{+} 7^{+}$proliferating dermal DCs in wild-type and WASp KO mice (Supplementary Fig. 1a). Wild-type mice had similar numbers of $\mathrm{CD} 4{ }^{+}$and $\mathrm{CD}^{+}{ }^{+} \mathrm{T}$ cells in the skin before and after Der p 2 challenge (Fig. 1d). WASp KO mice had decreased number of $\mathrm{CD}^{+} \mathrm{T}$ cells in unchallenged skin. Upon Der p 2 challenge, the number of $\mathrm{CD}^{+}{ }^{+} \mathrm{T}$ cells was increased in WASp KO mice and reached similar number to Der p 2-challenged wild-type mice (Fig. 1d). In contrast, unchallenged WASp KO mice had increased number of $\mathrm{CD}^{+}{ }^{+} \mathrm{T}$ cell in the skin compared with wild-type mice and the $\mathrm{CD}^{+}{ }^{+} \mathrm{T}$-cell population was further increased in WASp KO mice after Der p 2 challenge (Fig. 1d). To corroborate the results from histological analysis, we performed flow cytometry analysis of the $1 \mathrm{~cm}^{2}$ back skin challenged with Der p 2 (containing both macroscopically inflamed and non-inflamed skin). Upon Der p 2 challenge, wild-type and WASp KO mice had increased number of CD45 ${ }^{+}$hematopoietic cells in the skin when compared with unchallenged mice (Supplementary Fig. 1c). Der p 2 challenge induced increased number of $\mathrm{CD}_{11 \mathrm{~b}^{+}} \mathrm{CD}_{11 \mathrm{c}^{+}}$and $\mathrm{EpCAM}^{+}$ DCs in the WASp KO skin when compared with Der $p$ 2-challenged wild-type skin (Fig. 1e). However, due to the fact that we assessed both lesional and non-lesional skin by flow cytometry, Der $\mathrm{p} 2$ challenge did not induce a significant increase of $\mathrm{CD}_{4}^{+}$and $\mathrm{CD}^{+} \mathrm{T}$ cells in wild-type or WASp $\mathrm{KO}$ mice (Fig. 1e). WASp KO mice had fewer IFN $\gamma$-producing $\mathrm{CD}^{+}$ $\mathrm{T}$ cells when compared with wild-type mice both before and after Der p 2 challenge (Supplementary Fig. 1c). Moreover, WASp KO mice had a tendency to increased number of IFN $\gamma$ producing $\mathrm{CD}^{+}{ }^{+} \mathrm{T}$ cells and $\mathrm{CD} 11 \mathrm{c}^{+} \mathrm{EpCAM}^{-} \mathrm{CD} 103^{+} \mathrm{DCs}$ (Supplementary Fig. 1c).

On treatment with the TLR7 agonist imiquimod, wild-type mice exhibited increased numbers of migratory $\mathrm{MHCII}^{\text {high }} \mathrm{DEC}^{205}{ }^{+} \mathrm{CD} 8{ }^{-}$DCs and $\mathrm{CCR} 7{ }^{+} \mathrm{DEC}^{2} 05^{+} \mathrm{CD} 8{ }^{-}$ DCs in the dLNs, whereas WASp KO DCs failed to migrate to the dLNs (Fig. 1f). This implied that WASp KO skin DCs had decreased capacity to egress and therefore accumulated in the dermis.

When we analyzed the Der $\mathrm{p} 2$ response in dLNs and spleen, individual WASp KO mice showed a consistent increase in $\mathrm{CD}^{+} \mathrm{T}$ cells over $\mathrm{CD} 4^{+} \mathrm{T}$ cells leading to a skewed $\mathrm{CD} 4 / \mathrm{CD} 8$ T-cell ratio, although the mean total number of LN and spleen 
$\mathrm{CD}^{+}{ }^{+}$and $\mathrm{CD} 8{ }^{+} \mathrm{T}$ cells were similar in wild-type and WASp KO mice (Fig. 2a). Compared to LNs and spleen, WASp KO mice had a reversed CD4/CD8 ratio in blood, suggesting that WASp $\mathrm{KO} \mathrm{CD}{ }^{+} \mathrm{T}$ cells preferentially accumulated in tissues (Supplementary Fig. 2a). Wild-type and WASp KO mice had similar number of memory/effector $\mathrm{CD} 4{ }^{+} \mathrm{T}$ cells before and after Der p 2 challenge as determined by CD $44^{\text {high }} / \mathrm{CD} 62 \mathrm{~L}^{-}$cells
(Fig. 2b), but Der p 2 challenge induced higher number of memory/effector $\mathrm{CD}^{+} \mathrm{T}$ cells in the spleen of WASp KO mice when compared with wild-type mice (Fig. 2b).

Together, these results suggests that Der $\mathrm{p}$ 2-challenged WASp $\mathrm{KO}$ mice had an accumulation of DCs in the dermis and an altered systemic T-cell balance with increased number of effector/memory $\mathrm{CD}^{+} \mathrm{T}$ cells. a

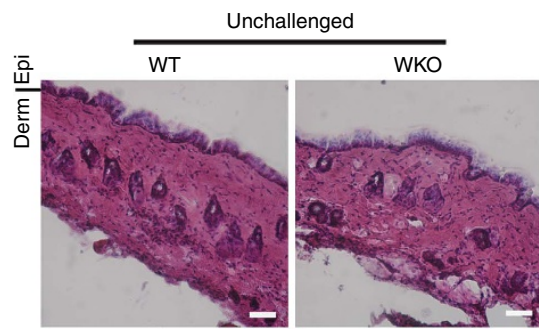

b
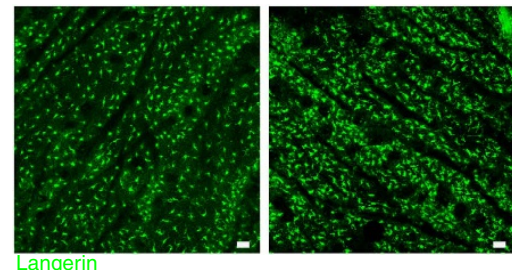

C
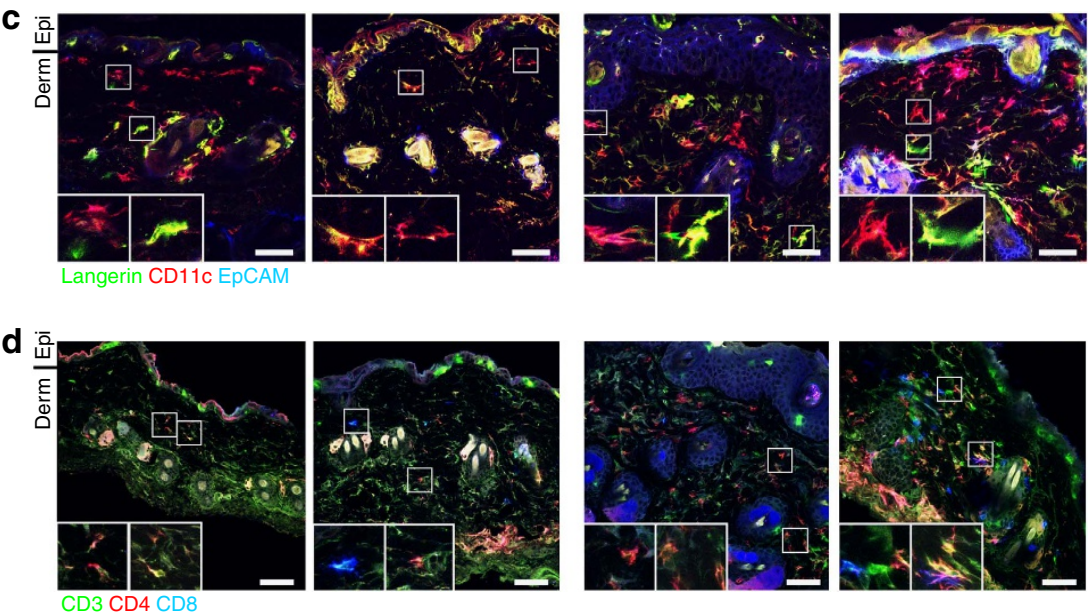

e

$\mathrm{CD} 11 \mathrm{~b}+\mathrm{CD} 11 \mathrm{c}+\mathrm{DCs}$
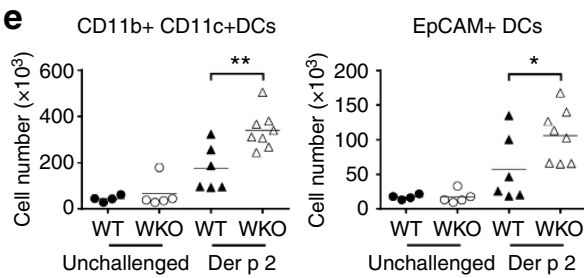

Der $\mathrm{p} 2$
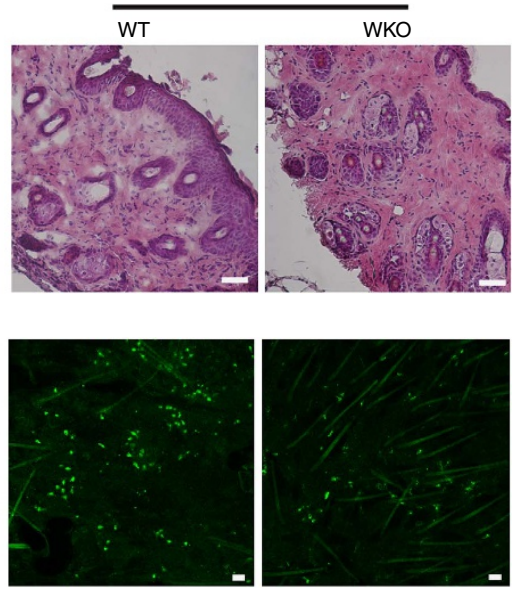
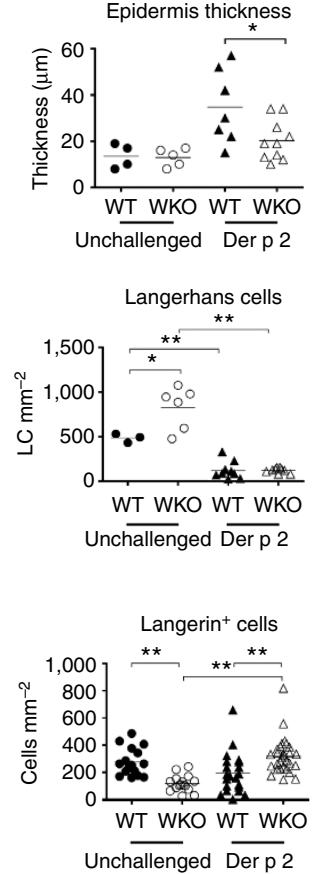

$\mathrm{CD}_{11 \mathrm{c}^{+} \mathrm{EpCAM}^{+} \text {cells }}$
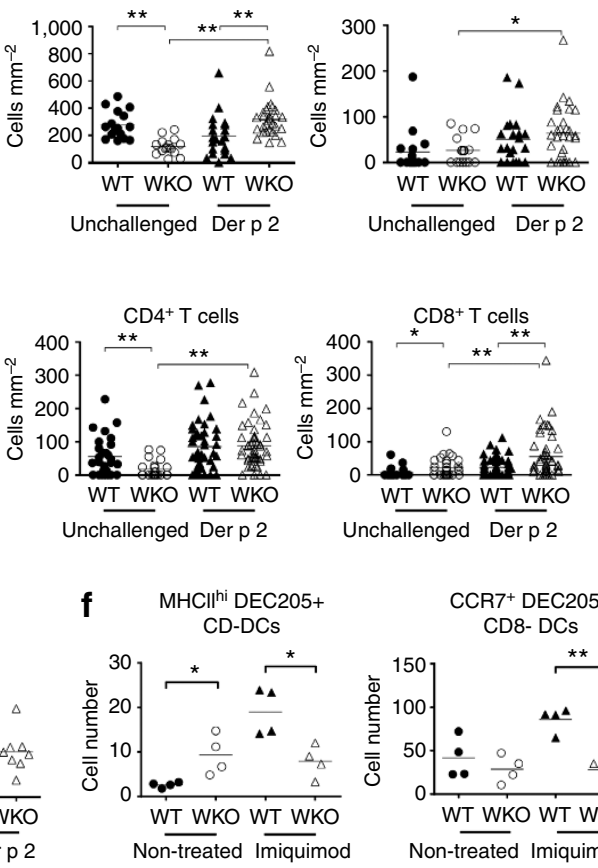

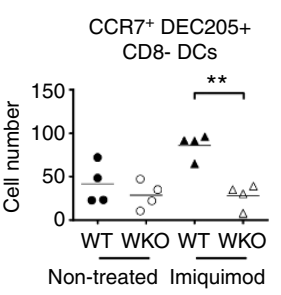

Figure 1 | Der $\mathbf{p} 2$ induces skin pathology in WASp KO mice. (a) Whole-skin sections (10 $\mu \mathrm{m})$ from $4 \mathrm{~mm}^{2}$ punch biopsies of back skin from day 50 were stained with hematoxylin and eosin. Epidermal thickening is indicated in $\mu \mathrm{m}$. (b) Langerhans cells in epidermis by histology. Epidermal sheets labelled with Langerin (CD207, green) for identification of Langerhans cells. The mean number of Langerhans cells per mm² of epidermis at day 50 is indicated. $(\mathbf{c}, \mathbf{d})$ DCs and T cells in dermis by histology. (c) The mean number of total Langerin ${ }^{+}$(including Langerhans and dermal DCs, green), CD11c ${ }^{+}$EpCAM ${ }^{+}$ (mature Langerhans cells, CD11c in red and EpCAM in blue) DCs and (d) CD4 ${ }^{+} \mathrm{CD} 3^{+}$(red and green, respectively) and CD8 $\beta^{+}\left(\right.$blue) $\mathrm{T}$ cells per mm ${ }^{2}$ is indicated. Examples of counted cells are magnified in the white boxes. (a-d) Bar represents mean value and each dot represents one mouse (a,b) or one picture $(\mathbf{c}, \mathbf{d})$. Results are a pool of two separate experiments. (a-d) WT unchallenged $n=3-4$; WKO unchallenged $n=3-6$; WT Der p $2 n=3-9$; WKO Der p $2 n=4-10$. Scale bar, $50 \mu \mathrm{m}$. (e) DCs and T cells in skin by flow cytometry analysis. Absolute numbers of cells in the back skin at day 50 from unchallenged and Der p 2-challenged WT and WASp KO mice as measured by flow cytometry. WT unchallenged $n=4 ;$ WKO unchallenged $n=5 ;$ WT Der p $2 n=6$; WASP KO Der p $2 n=8$. (f) DC egress from the skin. Imiquimod was applied on the ear and $48 \mathrm{~h} \mathrm{later,} \mathrm{MHCIIhigh} D E C 205^{+}$CD8 ${ }^{-}$DCs and $\mathrm{CCR}^{+}{ }^{+} \mathrm{DEC} 205^{+} \mathrm{CD} 8-$ DCs were analysed by flow cytometry in dLNs. WT unchallenged $n=4$; WKO unchallenged $n=4$; WT imiquimod $n=4$; WASP $\mathrm{KO}$ Imiquimod $n=4$. (a-f) Results are representative of two separate experiments. ${ }^{\star} P<0.05 ;{ }^{\star} P<0.01$ as calculated by the unpaired Student's $t$-test. LC, Langerhans cells; WT, wild type; WKO, WASp KO. 
a
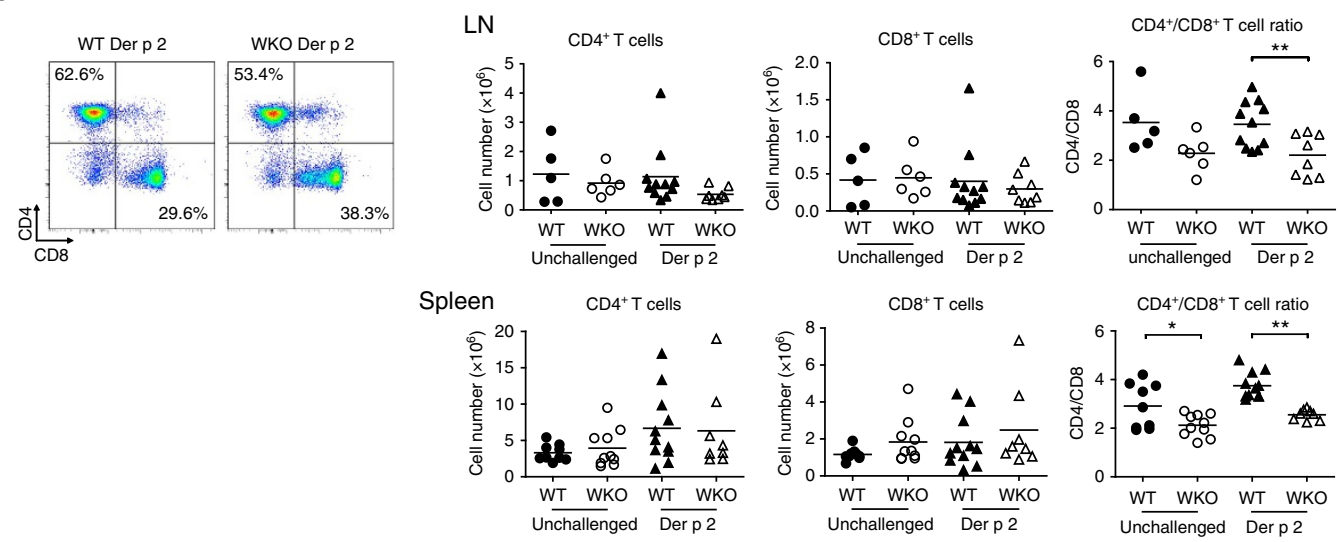

b
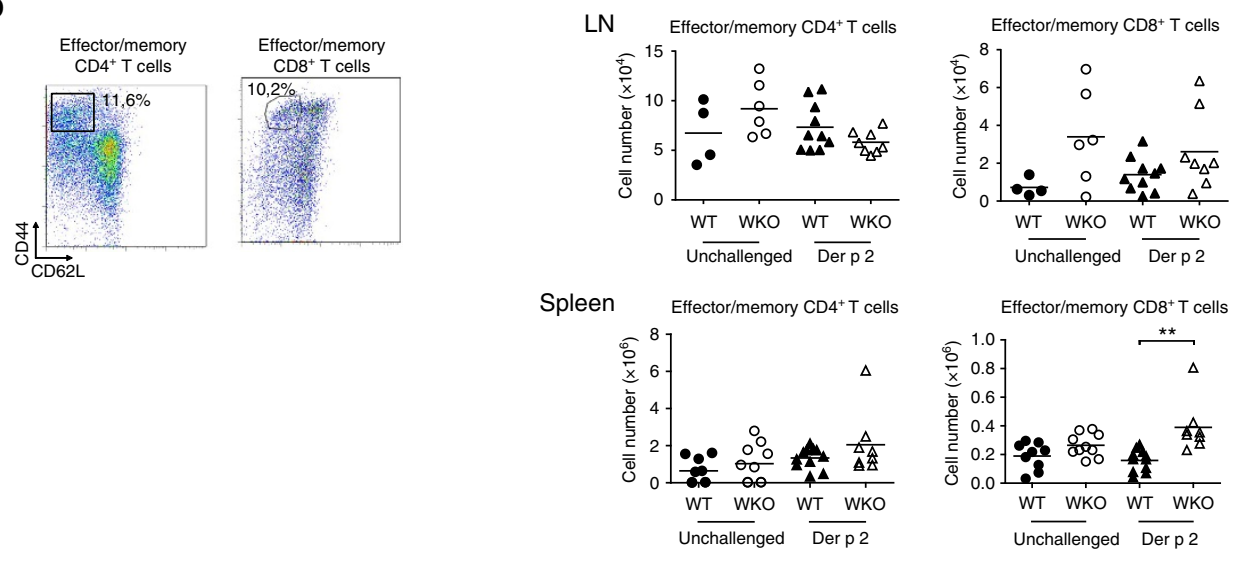

C
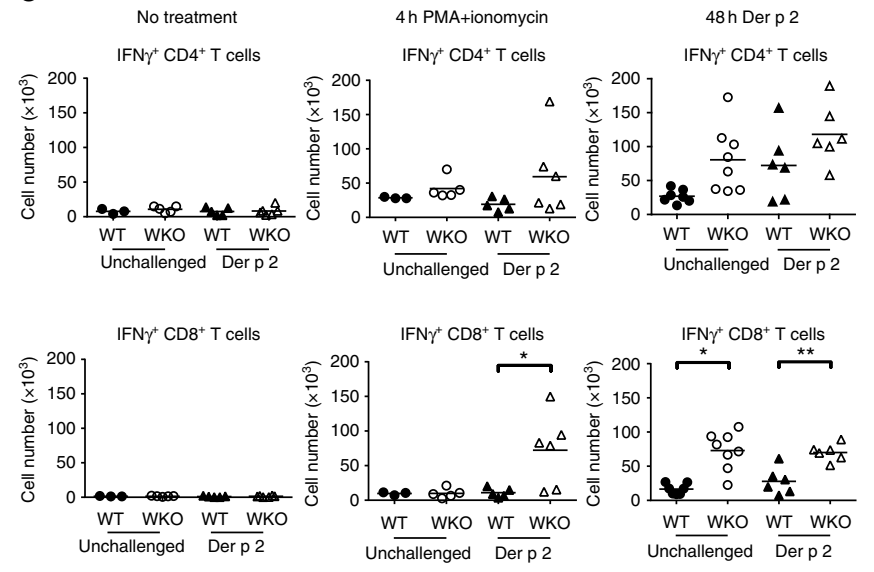

d
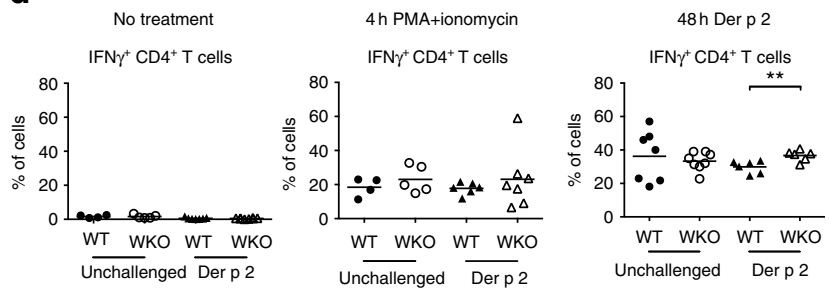

Figure 2 | Der $\mathbf{p} 2$ induces expansion of WASp KO CD8 ${ }^{+}$IFN $\gamma^{+} \mathbf{T}$ cells. (a,b) LN and spleen T cells by flow cytometry. Absolute numbers of (a) total and (b) effector/memory (CD44 $\left.{ }^{\text {hi }} \mathrm{CD} 62 \mathrm{~L}^{-}\right), \mathrm{CD}^{+}$and $\mathrm{CD} 8^{+} \mathrm{T}$ cells from day 50 spleens and dLNs from unchallenged and Der $\mathrm{p} 2$-challenged WT and WASp KO mice on Balb/c background as measured by flow cytometry. (c) In vitro stimulation of spleen cells. Total splenocytes from unchallenged or Der $\mathrm{p}$ 2-challenged mice at day 50 were either unstimulated or stimulated with PMA plus ionomycin for $4 \mathrm{~h}$ or Der $\mathrm{p} 2$ for $48 \mathrm{~h}$ (c). Absolute numbers of total $\mathrm{CD} 4{ }^{+} \mathrm{IFN} \gamma+$ and $\mathrm{CD} 8{ }^{+} \mathrm{IFN} \gamma+$ T cells after Der $\mathrm{p} 2$ and PMA plus ionomycin stimulation as measured by flow cytometry. (a-c) Bar represents mean value and each dot represents one mouse. (a,b) Results are a pool of two separate experiments and (c) representative of two separate experiments. (a,b) WT unchallenged $n=4-9$; WKO unchallenged $n=6-10$; WT Der p $2 n=10-11$; WKO Der p $2 n=8$. (c) WT unchallenged $n=3-7$; WKO unchallenged $n=5-8$; WT Der p $2 n=5-6$; WKO Der p $2 n=6$. ${ }^{\star} P<0.05$; ${ }^{\star} P<0.01$ as calculated by the unpaired Student's $t$-test. WT, wild type; WKO, WASp KO.

Der $\mathbf{p} 2$ induces expansion of WASp $\mathrm{KO} \mathrm{CD8}^{+} \mathrm{IFN} \gamma+\mathrm{T}$ cells. To examine the cytokine profile in WASp KO mice, we measured cytokines in serum and skin. Similar quantities of TNF $\alpha$, IL-4, IL-5, IL-6, IL-10, IL-13, IFN $\gamma$ and TGF $\beta$ in wild-type and WASp KO mice were detected both before and after Der $\mathrm{p} 2$ challenge (Supplementary Fig. 2b). When we examined the CD8 ${ }^{+} \mathrm{T}$ cells, there was no detectable IFN $\gamma$ production in freshly isolated cells from either wild-type or WASP KO mice (Fig. 2c,d). However, after $4 \mathrm{~h}$ stimulation with phorbol 12-myristate 13-acetate (PMA) and ionomycin, Der p 2-challenged WASp KO mice exhibited a high proportion of IFN $\gamma$-producing $\mathrm{CD}^{+}$ $\mathrm{T}$ cells (Fig. $2 \mathrm{c}, \mathrm{d}$ ). In splenocytes stimulated for $48 \mathrm{~h}$ with Der $\mathrm{p} 2$ 
to examine the allergen-specific response, both unchallenged and Der p 2-challenged WASp KO mice had increased number of IFN $\gamma$-producing $\mathrm{CD}^{+}{ }^{+} \mathrm{T}$ cells (Fig. $2 \mathrm{c}$,d). WASp KO T cells from unchallenged mice, not previously stimulated with Der $\mathrm{p} 2$, also showed expansion of $\mathrm{CD}^{+}{ }^{+} \mathrm{IFN} \gamma^{+} \mathrm{T}$ cells upon Der $\mathrm{p} 2$ treatment in vitro. Since few naive $\mathrm{T}$ cells will contain the Der $\mathrm{p} 2$ specificity, this suggests that naive WASp KO CD8 ${ }^{+}$ $\mathrm{T}$ cells, but not $\mathrm{CD} 4^{+} \mathrm{T}$ cells, were prone to produce IFN $\gamma$ irrespective of antigen specificity.

Increased WASp KO $\mathrm{CDB}^{+} \mathrm{IFNg}^{+} \mathrm{T}$ cells upon $L$. major infection. We next investigated how WASp KO mice would respond to dermal infection. Leishmania major (L. major) infect dermal macrophages and induce a massive Th1 response characterized by $\mathrm{CD} 4^{+} \mathrm{T}$ cells producing IFN $\gamma^{33,34}$. When compared with wild-type mice, WASp KO mice had a delayed response to L. major infection at 2 weeks post infection as evidenced by smaller lesion size (Fig. 3a; Supplementary Fig. 3a) and decreased
$\mathrm{CD}^{+}{ }^{-}$T-cell infiltration (Fig. 3b). At 6 weeks post L. major infection, both wild-type and WASp KO mice had large lesions (Fig. 3a; Supplementary Fig. 3a) with considerable infiltration of MHC class II ${ }^{\mathrm{hi}} \mathrm{DCs}, \mathrm{CD} 4^{+}$and CD8 ${ }^{+} \mathrm{T}$ cells and macrophages (Fig. 3b; Supplementary Fig. 3b,c). At 6 weeks, dLNs in wild-type mice had increased number of MHC class II ${ }^{\text {high }}$ DCs, which had likely emigrated from the infected skin (Fig. 3c). Moreover, wild-type mice had increased numbers of $\mathrm{CD} 103^{+}, \mathrm{CD} 8 \alpha^{+}$and $\mathrm{CD} 8 \alpha^{-}$DCs capable of cross-presenting exogenous antigen and activate $\mathrm{CD}^{+}{ }^{+} \mathrm{T}$ cells (Fig. 3c; Supplementary Fig. 3d). In contrast, WASp KO mice showed no increased numbers of MHC class II high DCs or $\mathrm{CD} 103^{+}, \mathrm{CD} 8 \alpha^{+}$and $\mathrm{CD} 8 \alpha^{-}$DCs in the dLNs upon infection (Fig. 3c; Supplementary Fig. 3d). Together with increased accumulation of DCs in the dermis of WASp KO mice after Der $\mathrm{p} 2$ challenge, this suggests that WASp KO DCs have decreased capacity to egress from dermis.

In the T-cell compartment of dLNs, WASp KO mice had significantly lower number of $\mathrm{CD} 4^{+} \mathrm{T}$ cells both at 2 and 6 weeks post infection when compared with wild-type mice
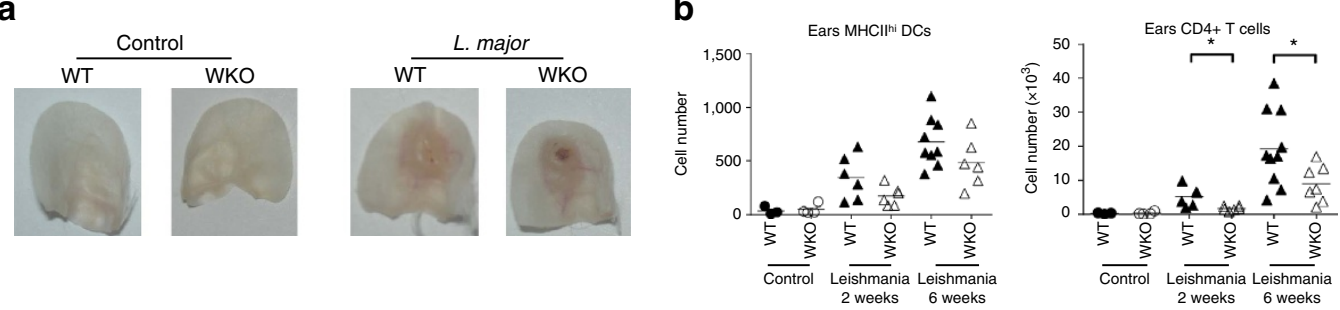

C
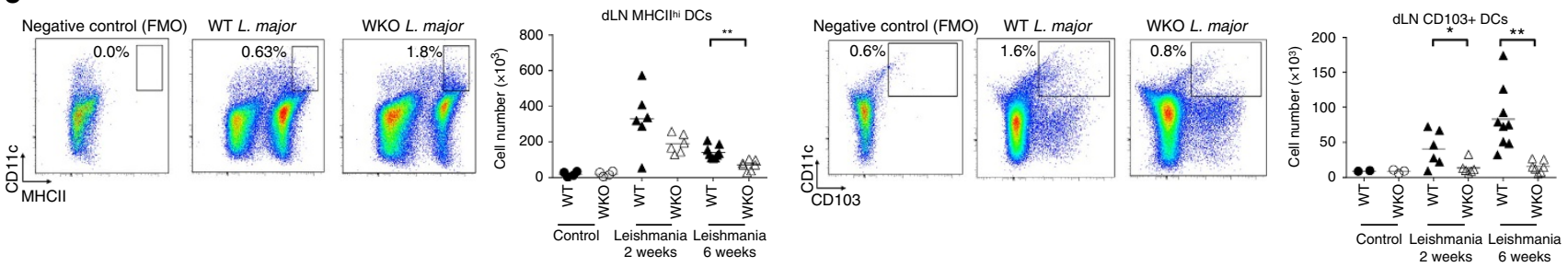

d
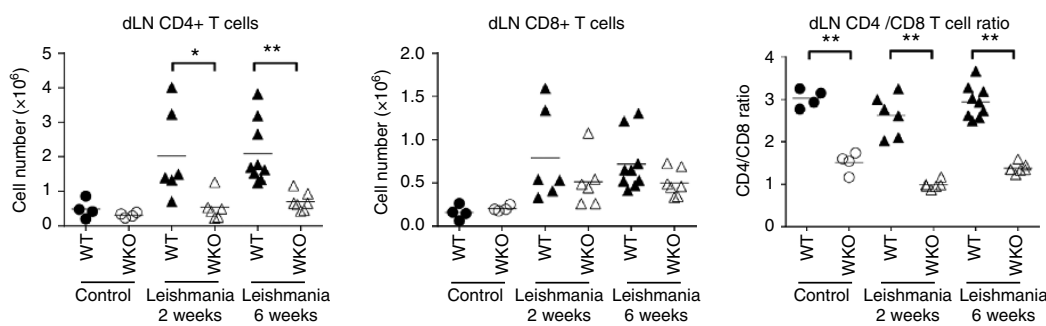

e
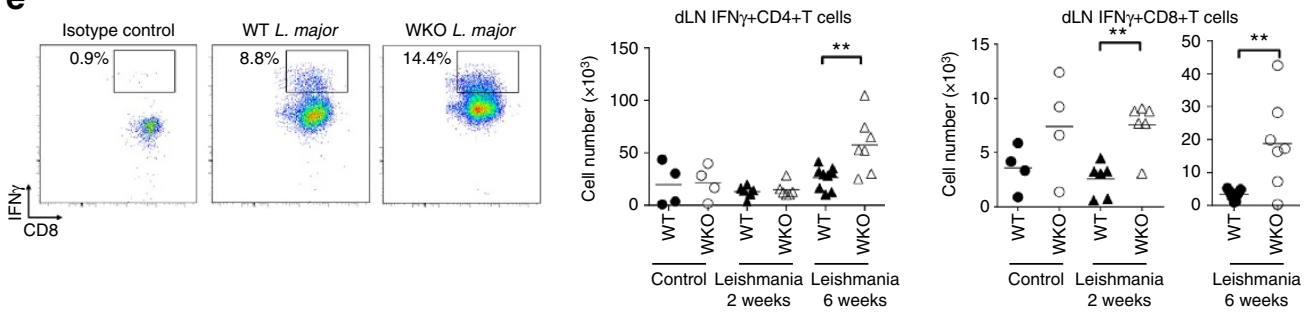

Figure 3 | L. major induces increased number of WASp KO CD8 ${ }^{+}$IFN $\gamma^{+}$T cells. (a) Ear infiltration of cells. (a) Ears from WT and WASp KO control or

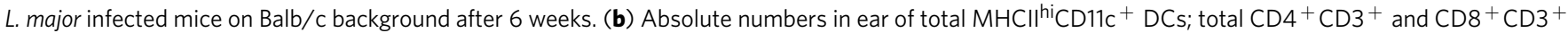
T cells, measured by flow cytometry. (c-e) dLN infiltration of cells. Absolute numbers in $\mathrm{dLN}$ of total $\mathrm{MHCIhti} D C s$; total $\mathrm{CD} 4^{+} \mathrm{CD}^{+}$and $\mathrm{CD} 8^{+}{ }^{+} \mathrm{CD} 3^{+}$ T cells; $\mathrm{CD}^{+} / \mathrm{CD} 8^{+} \mathrm{T}$-cell ratio; IFN $\gamma+{ }^{+} \mathrm{CD} 4^{+} \mathrm{CD}^{+}$and IFN $\gamma^{+} \mathrm{CD} 8{ }^{+} \mathrm{CD}^{+}$cells, measured by flow cytometry. (a-e) Bar represents mean value and each dot represents one ear or dLNs. Results from week 2 and week 6 are representative of two separate experiments. WT control $n=3-4 ;$ WKO control $n=4$; WT L. major 2 weeks $n=6$; WASp KO L. major 2 weeks $n=6$; WT L. major 6 weeks $n=10$; WASp KO L. major 6 weeks $n=7$. ${ }^{\star} P<0.05$; ${ }^{\star}{ }^{*}<0.01$ as calculated by the unpaired Student's $t$-test. FMO, fluorescence minus one (negative control for MHC class II and CD103); WT, wild type; WKO, WASp KO. 
(Fig. 3d). While the total number of CD8 ${ }^{+} \mathrm{T}$ cells was similar in wild-type and WASp KO dLNs upon L. major infection, WASp $\mathrm{KO}$ mice showed a consistent failure to accumulate $\mathrm{CD} 4{ }^{+} \mathrm{T}$ cells in dLNs leading to a skewed CD4/CD8 T-cell ratio irrespective of L. major infection (Fig. 3d). We detected similar number of IFN $\gamma$-producing $\mathrm{CD}^{+}{ }^{+}$and $\mathrm{CD}^{+}{ }^{+} \mathrm{T}$ cells in the dLNs of wild-type mice before and after L. major infection (Fig. 3e). In contrast, WASp $\mathrm{KO}$ mice had increased number of IFN $\gamma$-producing $\mathrm{CD}^{+}$and $\mathrm{CD}^{+} \mathrm{T}$ cells in the dLNs (Fig. 3e). Together, this data suggests that WASp KO mice, despite having less antigen-presenting DCs in dLNs, can activate IFN $\gamma$-producing $\mathrm{CD}^{+}$and $\mathrm{CD}^{+} \mathrm{T}$ cells upon L. major infection.

DC-specific WASp deletion induces increased $\mathrm{CD8}^{+} \mathrm{T}$ cells. To determine if WASp KO DCs induce expansion of wild-type $\mathrm{CD}^{+} \mathrm{T}$ cells, we took advantage of mice harbouring a conditionally targeted loxP-flanked WASp allele ${ }^{35}$ bred to mice expressing Cre recombinase under the DC-expressed CD11c promoter (CD11 $c^{\mathrm{Cre} / \mathrm{wt}}$ mice), referred to as $\mathrm{DC} / \mathrm{cWKO}$ mice (Fig. 4a). In DC/cWKO mice, WASp expression was efficiently deleted in $\mathrm{CD}_{11 c^{+}}$DCs and a large fraction of $\mathrm{CD}^{+}$and $\mathrm{CD}^{-}$DCs had decreased to absent expression of WASp (Fig. 4b,c; images in Fig. $4 \mathrm{~b}$ have been cropped for presentation. Full size images are presented in Supplementary Fig. 4). CD11c-driven deletion of WASp led to the absence of WASp in $10 \%$ of $\mathrm{CD}^{+} \mathrm{T}$ cells and $30 \%$ of $\mathrm{CD} 8{ }^{+} \mathrm{T}$ cells (Fig. 4b,c). When comparing maturation and activation phenotype to wild-type $\mathrm{CD} 8{ }^{+} \mathrm{DCs}, \mathrm{DC} / \mathrm{cWKO} \mathrm{CD}^{+}{ }^{+} \mathrm{DCs}$ had lower expression of MHC class II and CD86, while expression of MHC class I and II, and CD86 was similar in wild-type and DC/cWKO CD8 ${ }^{-}$DCs (Supplementary Fig. 5). When compared with wild-type mice, DC/cWKO mice had increased numbers of $\mathrm{CD} 8^{+} \mathrm{T}$ cells and decreased number of $\mathrm{CD}^{+} \mathrm{T}$ cells both in the LNs and spleen, creating a skewed CD4/CD8 T-cell ratio (Fig. 4d,e). Moreover, DC/cWKO mice had increased number of effector/memory $\mathrm{CD} 8{ }^{+} \mathrm{T}$ cells both in the LNs and spleen when compared with wild-type mice while effector/memory $\mathrm{CD}^{+}{ }^{+} \mathrm{T}$ cells were similar in wild-type and $\mathrm{DC} / \mathrm{cWKO}$ mice (Fig. 4f). This data indicates that reduced expression of WASp in $\mathrm{CD}_{11 c^{+}} \mathrm{DCs}$ was associated with expansion and activation of wild-type CD8 ${ }^{+} \mathrm{T}$ cells.

Increased cross-presentation by WASp KO DCs. The increased expansion of CD8 ${ }^{+} \mathrm{T}$ cells in WASp $\mathrm{KO}$ and $\mathrm{DC} / \mathrm{cWKO}$ mice led us to investigate if WASp KO DCs would have increased capacity to cross-present exogenous antigen and activate $\mathrm{CD} 8^{+}$ $\mathrm{T}$ cells. To address this possibility, wild-type CD ${ }^{+} \mathrm{T}$ cells from OT-I TCR transgenic mice were used in which all CD8 ${ }^{+} \mathrm{T}$ cells recognize the SIINFEKL peptide from ovalbumin presented by $\mathrm{H}-2 \mathrm{~K}^{\mathrm{b}} \mathrm{MHC}$ class I molecules. Wild-type and WASp KO CD8 ${ }^{+}$ DCs and $\mathrm{CD} 8^{-}$DCs, loaded with soluble ovalbumin, had similar capacity to form immune synapses with OT-I CD8 ${ }^{+} \mathrm{T}$ cells (Fig. 5a). When comparing direct presentation of the SIINFEKL peptide, we detected similar proliferation of OT-I CD8 ${ }^{+}$T cells when stimulated with wild-type or WASp $\mathrm{KO} \mathrm{CD}^{+}$or $\mathrm{CD} 8^{-}$ DCs (Fig. 5b). These findings suggest that WASp KO DCs could form immune synapses with $\mathrm{CD}^{+} \mathrm{T}$ cells to facilitate their activation. To examine the cross-presenting capacity, we compared $\mathrm{CD}^{+}$DCs with high capacity to cross-present soluble antigens and $\mathrm{CD}^{-}{ }^{-} \mathrm{DCs}$ with less capacity to cross-present soluble antigens ${ }^{21}$. Wild-type and WASp KO CD8 ${ }^{+}$DCs had similar capacity to induce OT-I $\mathrm{CD}^{+}{ }^{+} \mathrm{T}$-cell proliferation in response to soluble ovalbumin (Fig. $5 \mathrm{c}$ ). In contrast, WASp KO $\mathrm{CD}^{-}$DCs induced increased OT-I CD8 ${ }^{+}$T-cell proliferation when compared with wild-type $\mathrm{CD} 8{ }^{-}$DCs as determined by dilution of CFSE (Fig. 5c) and ${ }^{3} \mathrm{H}$-thymidine incorporation (Supplementary Fig. 5). CD8 ${ }^{-}$DCs, and to a lesser extent $\mathrm{CD}^{+}$DCs, can efficiently take up antigen in the form of immune complex by Fc receptors and shuttle the antigen into the cross-presentation pathway ${ }^{23,24}$. When compared with wild-type $\mathrm{CD}^{-}$DCs, WASp $\mathrm{KO} \mathrm{CD}^{-}$DCs had reduced capacity to cross-present antigen from immune complexes leading to decreased proliferation of OT-I CD8 ${ }^{+} \mathrm{T}$ cells (Supplementary Fig. $7 \mathrm{a}-\mathrm{c})$. We next examined antigen processing and presentation on MHC class II using soluble ovalbumin. Wild-type and WASp $\mathrm{KO} \mathrm{CD}^{+}$had similar capacity to stimulate proliferation of ovalbumin-specific OT-II $\mathrm{CD} 4^{+}$ $\mathrm{T}$ cells. In contrast, WASp $\mathrm{KO} \mathrm{CD}^{-}$DCs induced less proliferation when compared with wild-type $\mathrm{CD}^{-}$DCs (Supplementary Fig. 8). This suggests that WASp KO CD8 ${ }^{-}$ DCs favoured presentation of soluble ovalbumin on MHC class I molecules.

We next tried to identify the cause for the increased capacity of WASp $\mathrm{KO} \mathrm{CD}^{-}$DCs to cross-present soluble ovalbumin and stimulate proliferation of $\mathrm{CD}^{+} \mathrm{T}$ cells. Wild-type and WASp KO DCs had similar maturation phenotype as assessed by upregulation of CD86 and MHC class I molecules (Supplementary Fig. 5); normal uptake of soluble ovalbumin (Fig. 5d); and normal degradation of ovalbumin as determined by usage of DQ-OVA that start to emit fluorescence when ovalbumin is processed in the cell (Fig. 5e). For crosspresentation to occur, DCs need to maintain a near neutral $\mathrm{pH}$ of the phagosome that allows for escape of proteins to the cytosol and loading on MHC class I molecules ${ }^{20}$. To examine acidification, we used $\mathrm{pH}$ rodo-ovalbumin that emits fluorescence at low $\mathrm{pH}(\mathrm{pH} 3-5)$, indicating when ovalbumin reaches lysosomes. Wild-type $\mathrm{CD}^{+}$DCs had a lower percentage of pHrodo high cells when compared with wild-type CD8 ${ }^{-}$DCs (Fig. 5f), showing the low capacity of $\mathrm{CD}^{+}$DCs to acidify endosomes. WASp $\mathrm{KO} \mathrm{CD}^{+}$DCs showed similar low percentage of $\mathrm{pHrodo}^{\text {high }}$ cells as wild-type $\mathrm{CD}^{+} \mathrm{DCs}$ (Fig. 5f). In contrast to wild-type $\mathrm{CD}^{-}$DCs with increased percentage of pHrodo $^{\text {high }}$ cells, WASp $\mathrm{KO} \mathrm{CD}^{-}$DCs had decreased percentage of pHrodo $^{\text {high }}$ cells (Fig. 5f). To evaluate presentation of ovalbumin peptides on MHC class I molecules, DCs were incubated with soluble ovalbumin and labelled with an antibody specific for the ovalbumin peptide SIINFEKL presented by MHC class I molecule $\mathrm{H}-2 \mathrm{~K}^{\mathrm{b}}$. Wild-type and WASp KO $\mathrm{CD}^{+}$DCs had similar expression of SIINFEKL-H- $2 \mathrm{~K}^{\mathrm{b}}$ on the surface (Fig. 5g). When compared with wild-type CD8 ${ }^{-}$DCs, WASp KO CD8 ${ }^{-}$DCs presented more SIINFEKL in the context of $\mathrm{H}-2 \mathrm{~K}^{\mathrm{b}}$ (Fig. $5 \mathrm{~g}$ ).

To precisely determine the cross-presentation and acidification capacity of DCs, we used latex beads that were coated with ovalbumin (Fig. 6a). To circumvent differences in uptake of beads, DCs that had taken up one ovalbumin-coated bead (Fig. 6a) were sorted by flow cytometry and examined for their capacity to induce cross-presentation. Wild-type and WASp KO $\mathrm{CD}^{+}{ }^{+} \mathrm{DCs}$ induced high proliferation of OT-I CD8 ${ }^{+} \mathrm{T}$ cells when compared with wild-type $\mathrm{CD}^{-}$DCs (Fig. 6b). Again, WASp $\mathrm{KO} \mathrm{CD} 8{ }^{-}$DCs induced higher proliferation of OT-I $\mathrm{CD}^{+} \mathrm{T}$ cells when compared with wild-type $\mathrm{CD} 8^{-} \mathrm{DCs}$ (Fig. 6b). To assess if increased cross-presentation by WASp KO $\mathrm{CD}^{-}{ }^{-}$DCs was associated with changes in acidification upon phagocytosis, we first examined the early acidification events using beads bearing a mixture of $\mathrm{pH}$-sensitive (FITC) and $\mathrm{pH}$-insensitive (Alexa-fluor647) dyes that allows detection of phagosomal pH 5-8 (ref. 36). Using this approach, WASp KO $\mathrm{CD}^{+}$DCs maintained their phagosomes at a higher $\mathrm{pH}$ during the first $2 \mathrm{~h}$ after phagocytosis when compared with wild-type 
a
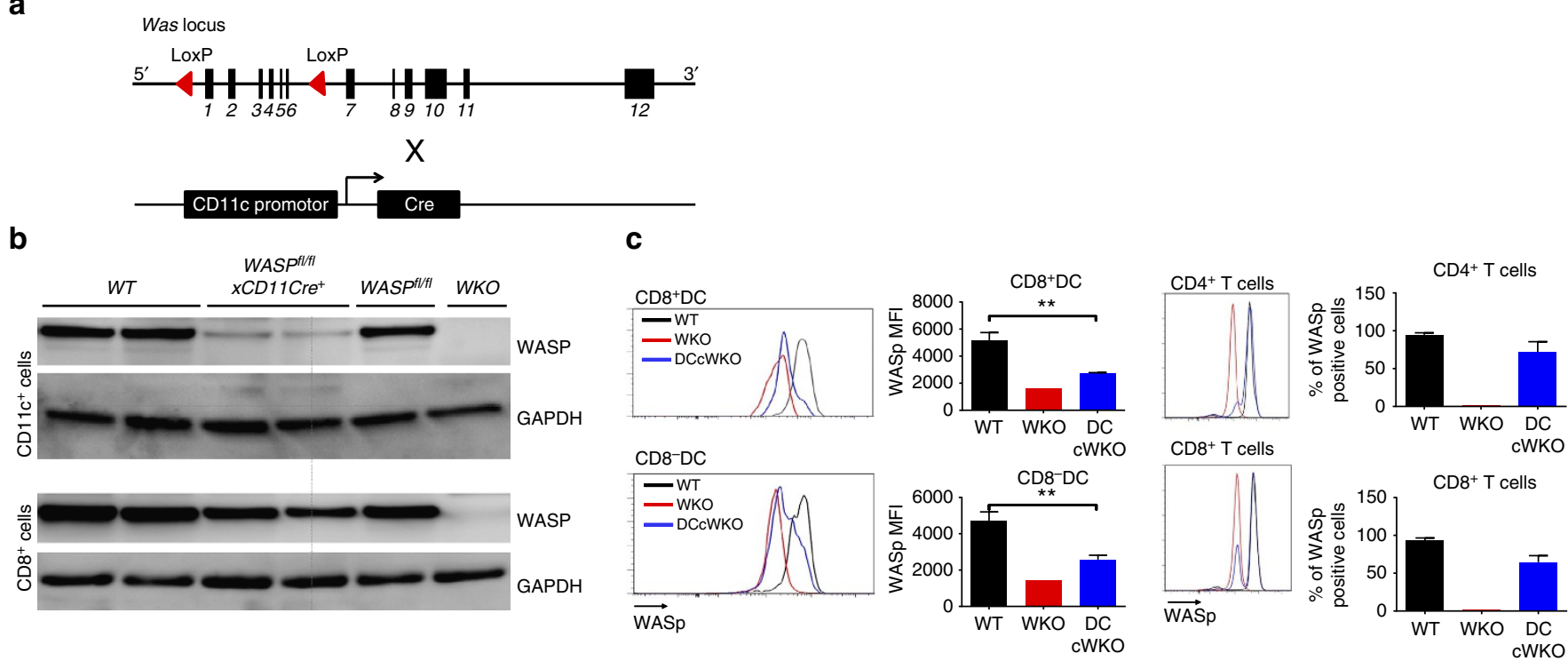

d
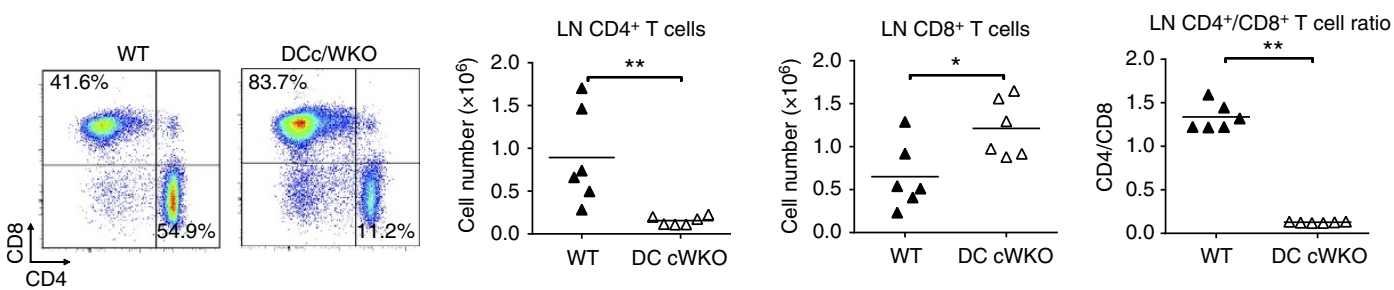

e
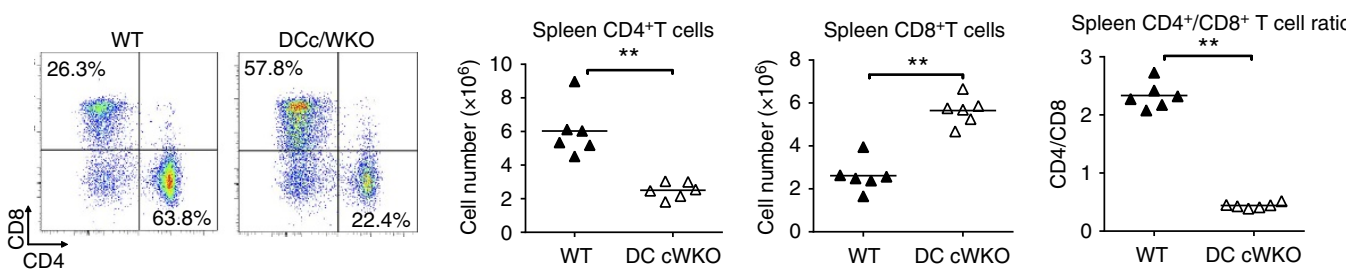

f
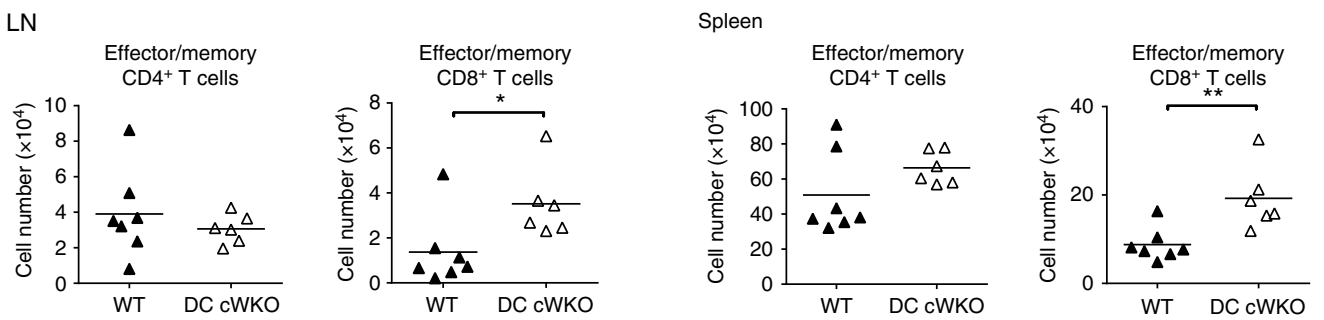

Figure 4 | DC-specific WASp deletion induces increased CD8 ${ }^{+} \mathbf{T}$ cells. (a) Schematic representation of the targeting strategy. Mice containing the WAS allele flanked by loxP sites were bred with CD11c-Cre mice to generate DC/cWKO mice on C57BI/6 background. (b,c) WASp expression as determined by (b) western blotting and (c) flow cytometry of $\mathrm{CD} 11 \mathrm{c}^{+} \mathrm{CD} 8+, \mathrm{CD} 11 \mathrm{c}^{+} \mathrm{CD} 8^{-}, \mathrm{CD} 4^{+} \mathrm{CD} 3^{+}$and $\mathrm{CD} 8^{+} \mathrm{CD} 3^{+}$cells from spleen. $(\mathbf{d}, \mathbf{e})$ Flow cytometry analysis of total $\mathrm{CD}_{4}{ }^{+} \mathrm{CD} 3^{+}$and $\mathrm{CD} 8^{+} \mathrm{CD} 3^{+}$T cells in the (d) $\mathrm{LNs}$ and (e) spleen and (f) total effector/memory $\left(\mathrm{CD} 44^{\mathrm{hi}} \mathrm{CD} 62 \mathrm{~L}^{-}\right) \mathrm{CD}^{+}{ }^{+} \mathrm{CD} 3^{+}$and $\mathrm{CD} 8{ }^{+} \mathrm{CD} 3^{+}$T cells in $\mathrm{LNs}$ and spleen. (c) Bar represents mean \pm s.d. of $\mathrm{WT} n=3 ; \mathrm{WKO} n=1 ; \mathrm{DC} / \mathrm{cWKO} n=3$. (d,f) WT $n=6-7$; DC/cWKO $n=6$. The data is representative of (b) one, (c) two, (d,e) four and (f) two separate experiments. ${ }^{\star} P<0.05 ;{ }^{\star \star} P<0.01$ as calculated by the unpaired Student's t-test. DC/cWKO, WASp ${ }^{\mathrm{fl} / \mathrm{fl}} \mathrm{CD} 11 \mathrm{c}$ Cre/wt; fl, floxed (LoxP flanked); WT, wild type; WKO, WASp KO.

$\mathrm{CD}^{+}$DCs (Fig. 6c). For CD8 ${ }^{-}$DCs, wild-type and WASp KO DCs showed similar phagosomal $\mathrm{pH}$ at $30 \mathrm{~min}$ and $2 \mathrm{~h}$ (Fig. $6 \mathrm{c}$ ). To examine the later acidification events, we used beads coated with $\mathrm{pH}$ rodo-ovalbumin that measures phagolysosomal $\mathrm{pH} 3-5$. When compared with wild-type $\mathrm{CD}^{+}{ }^{+} \mathrm{DCs}$, WASp $\mathrm{KO} \mathrm{CD} 8^{+}$ DCs showed decreased percentage of pHrodohigh cells after $6 \mathrm{~h}$ (Fig. 6d). Also for $\mathrm{CD}^{-}$DCs, WASp KO CD8 ${ }^{-}$DCs showed

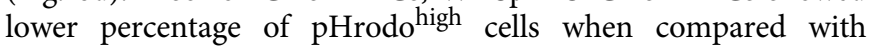

wild-type $\mathrm{CD}^{-}$DCs (Fig. $6 \mathrm{~d}$ ). To confirm that the $\mathrm{pH}$ rodo fluorescence represented acidification, cells were pre-treated with $\mathrm{NH}_{4} \mathrm{Cl}$ that completely abolished acidification of $\mathrm{pH}$ rodoovalbumin-coated beads (Fig. 6e). Together, this data suggests that WASp $\mathrm{KO} \mathrm{CD} 8^{-}$DCs had decreased capacity to acidify endocytic and phagocytic vesicles and this was associated with cross-presentation on MHC class I and increased proliferation of $\mathrm{CD}^{+} \mathrm{T}$ cells. 
a

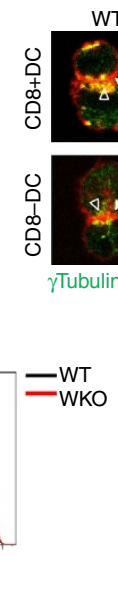

C
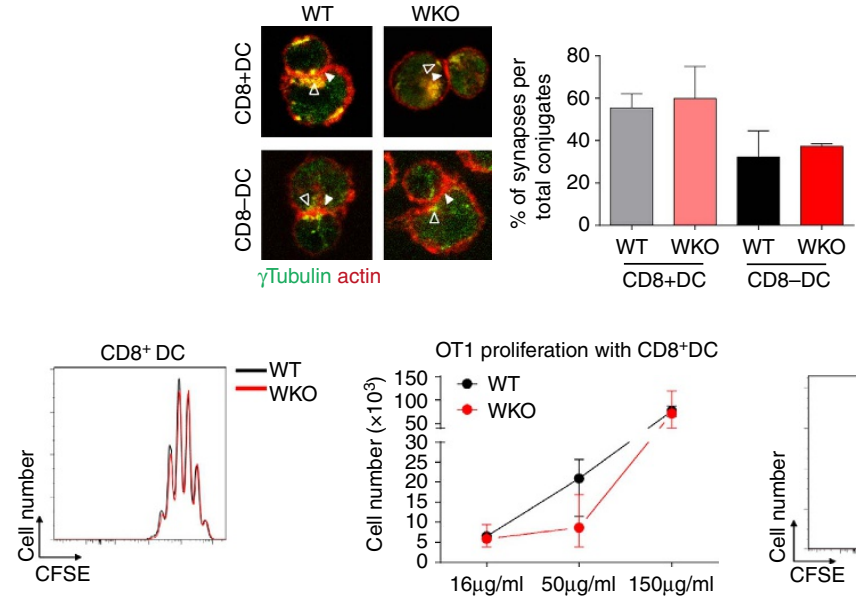

b

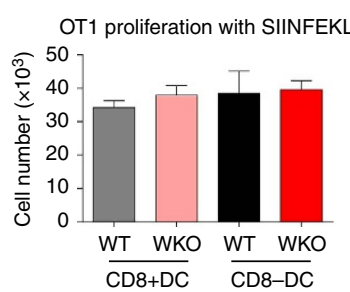

d
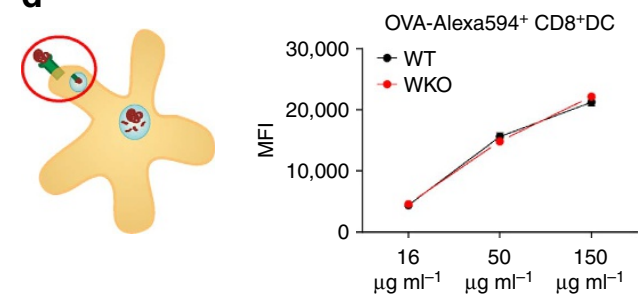

e
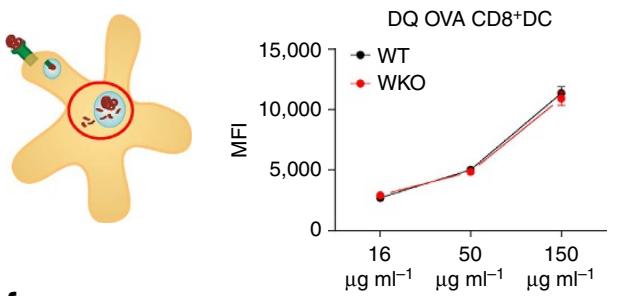
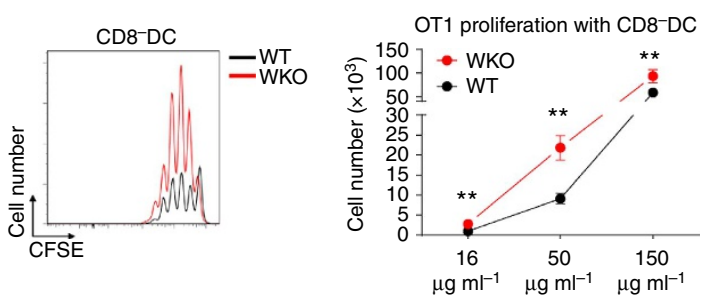

g
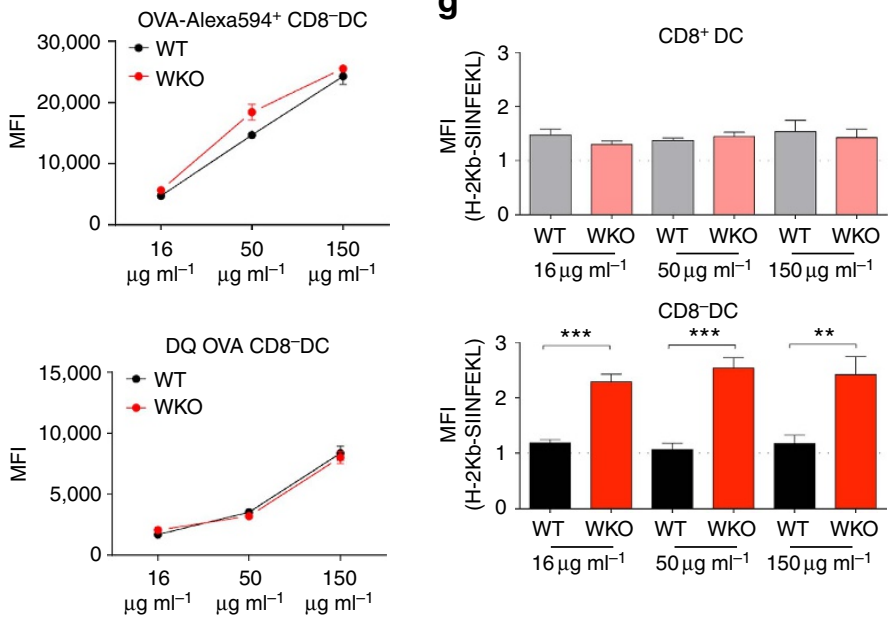

f
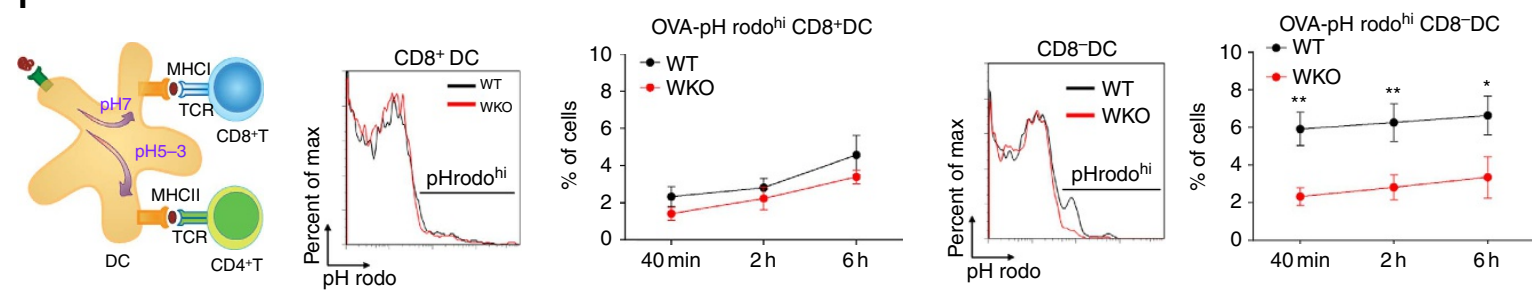

Figure 5 | Increased cross-presentation by WASp KO DCs. (a) Immune synapse. Enriched CD8 ${ }^{+}$and $\mathrm{CD}^{-}$DCs from Flt3L tumour cell-injected mice on C57BI/6 background were pulsed with ovalbumin and incubated with OT-I CD8 ${ }^{+}$T cells. Percentage of synapses was measured by counting the number of conjugates with polarized actin (red) and microtubule organizing center $\gamma$-tubulin (green) towards the synapse and divided by the total number of cell conjugates. (b) $\mathrm{CD}^{+}{ }^{+}$T-cell proliferation with SIINFEKL peptide. Enriched CD8 ${ }^{+}$and $\mathrm{CD}^{-} \mathrm{DCs}$ from Flt3L tumour cell-injected mice on C57BI/6 background were incubated overnight with $2 \mu \mathrm{g} \mathrm{ml}{ }^{-1}$ SIINFEKL peptide and co-cultured with CFSE-labelled OT-I (V $\left.\beta 5.1 / 5.2^{+}\right)$CD8 ${ }^{+} \mathrm{T}_{\text {cells }}$ for $72 \mathrm{~h}$. Total number of OT-I CD8 ${ }^{+}$T cells is indicated. (c) CD8 ${ }^{+}$T-cell proliferation with ovalbumin. Equal numbers of FACS-sorted splenic CD8 ${ }^{+} \mathrm{DCs}_{\text {and }}$ CD8 ${ }^{-}$DCs from wild-type and WASp KO mice on C57BI/6 background were incubated overnight with ovalbuminm, co-cultured with CFSE-labelled OT-I $\left(\mathrm{V} \beta 5.1 / 5.2^{+}\right) \mathrm{CD}^{+}{ }^{+} \mathrm{T}$ cells, and proliferation determined at $72 \mathrm{~h}$. Total number of OT-I CD8 ${ }^{+} \mathrm{T}$ cells is indicated. (d) Ovalbumin uptake. DCs were incubated with soluble ovalbumin-Alexa594 to assess uptake of ovalbumin. (e) Ovalbumin degradation. DCs were incubated with soluble DQ-ovalbumin to assess the capacity to process antigen. Note that increased DQ-ovalbumin mean fluorescence intensity indicates increased degradation. (f) Ovalbumin acidification. DCs were incubated with soluble $\mathrm{pH}$ rodo-ovalbumin. Note that increased $\mathrm{pH}$ rodo-ovalbumin mean fluorescence intensity indicates decreased $\mathrm{pH}$ value. $(\mathbf{g}) \mathrm{CD} 8^{+} \mathrm{DCs}$ and $\mathrm{CD} 8^{-} \mathrm{DCs}$ from wild-type and WASp KO mice were incubated overnight with ovalbumin. The presentation of SIINFEKL peptide on MHC class I H-2 $\mathrm{K}^{\mathrm{b}}$ molecules was assessed by flow cytometry and fold increase in expression was determined using the MFI value acquired for $0 \mu \mathrm{g} \mathrm{ml}^{-1}$ ovalbumin set to 1 (dotted line) (a) A total of 39-113 conjugates per mouse was analyzed. (a-g) Bar represents mean \pm s.d. of WT $n=3$; WKO $n=3$ per group. The data is representative of $(\mathbf{a}, \mathbf{b}, \mathbf{g})$ two experiments, (c) four experiments and $(\mathbf{d}-\mathbf{f})$ three separate experiments. ${ }^{\star} P<0.05$; ${ }^{\star \star} P<0.01$ as calculated by the unpaired Student's $t$-test. MFI, mean fluorescence intensity; WT, wild type; WKO, WASp KO.

WASp KO CD8 ${ }^{-}$DCs activate Rac2 and ROS production. $\mathrm{CD} 8{ }^{+}$DCs assemble a phagosomal complex consisting of Rac2 and the NADPH complex to maintain a neutral $\mathrm{pH}$ of the phagosome ${ }^{21,36}$. To study Rac2 expression and co-localization to the phagosome, we incubated wild-type and WASp $\mathrm{KO} C D 8^{+}$ and CD8 ${ }^{-}$DCs with ovalbumin-coated beads and stained for Rac1 and Rac2. Rac1 expression was higher in CD8 ${ }^{+}$DCs than in $\mathrm{CD} 88^{-}$DCs and this was detected both in wild-type and WASp 
a
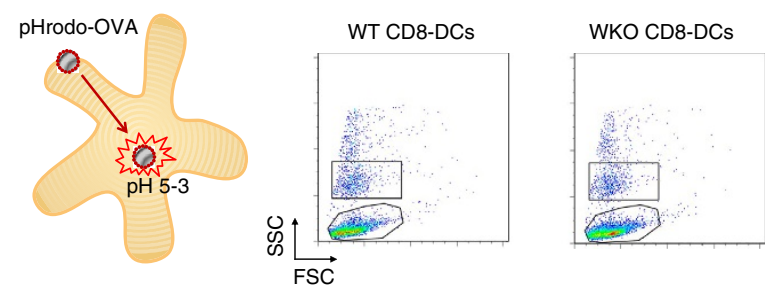

b
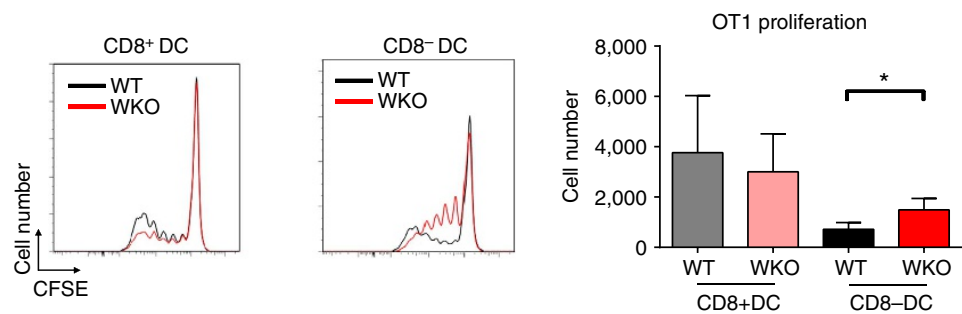

C
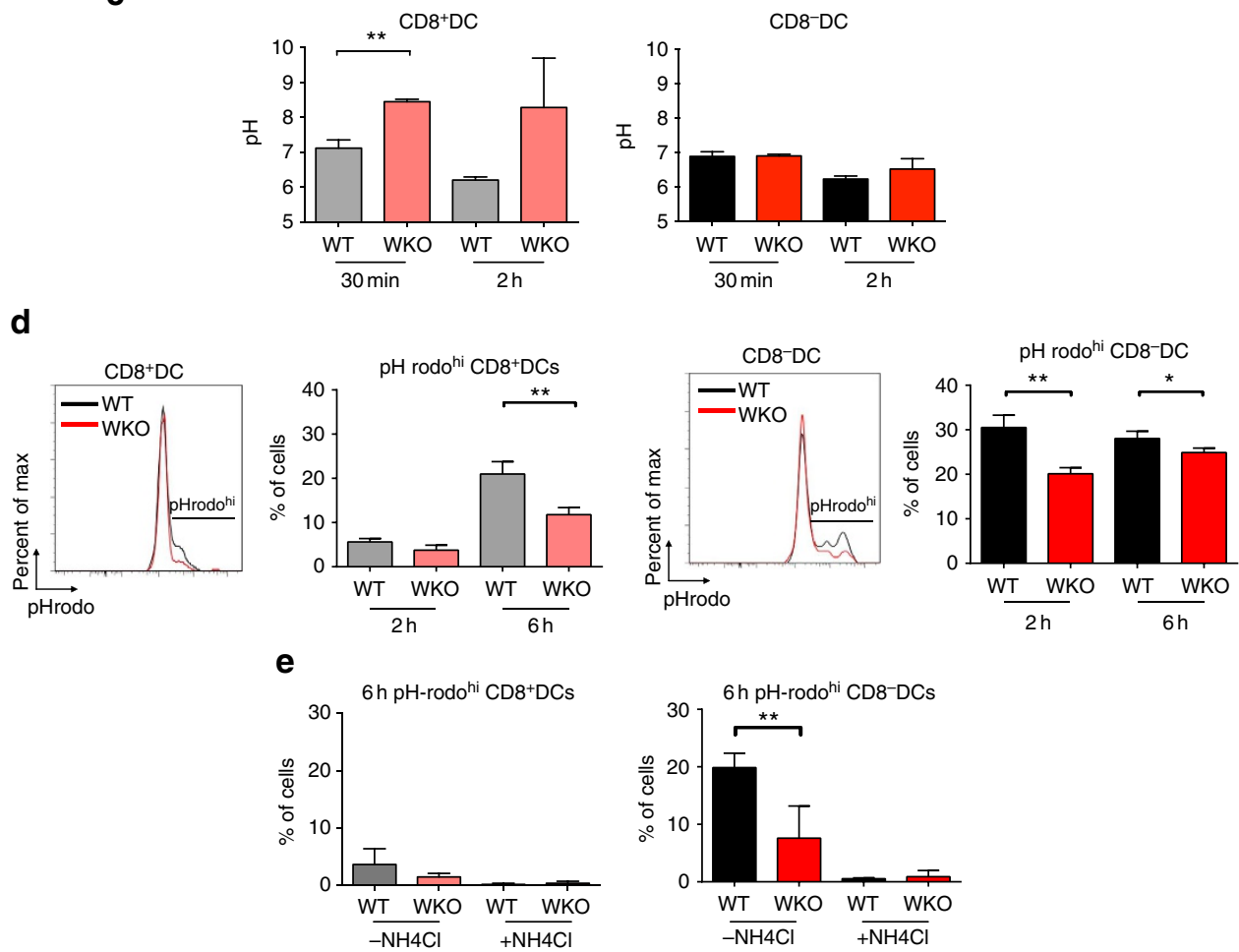

Figure 6 | The phagosomal compartment in WASp KO DCs. Wild-type and WASp KO CD8 ${ }^{+}$and CD8 ${ }^{-}$DCs from mice on C57BI/6 background were incubated with ovalbumin-coated latex beads overnight. (a) Ovalbumin-bead uptake by DCs. (b) $\mathrm{CD}^{+}{ }^{+} \mathrm{T}$-cell proliferation with ovalbumin-coated beads. FACS-sorted DCs that had taken up one ovalbumin-coated bead were co-cultured with CFSE-labelled OT-I $\left(V \beta 5.1 / 5.2^{+}\right) \mathrm{CD}^{+}{ }^{+} \mathrm{T}$ cells, and proliferation determined as CFSE dilution at $72 \mathrm{~h}$. (c) DCs were incubated with latex beads coupled with pH-sensitive (FITC) and pH-insensitive (Alexa647) dyes. FITC and Alexa647 intensities were measured at the specified time points and the pH was determined as described in the materials and methods.

(d,e) Ovalbumin-bead acidification. (d) DCs were incubated with pH rodo-ovalbumin-coated beads to assess acidification of antigen in phagocytic vesicles. Note that increased $\mathrm{pH}$ rodo mean fluorescence intensity translates into decreased $\mathrm{pH}$ value. (e) $\mathrm{DCs}$ were pre-treated with $\mathrm{NH}_{4} \mathrm{Cl}$ to abolish acidification before addition of $\mathrm{pH}$ rodo-ovalbumin beads. (b-e) Bar represents mean \pm s.d. of WT $n=3$; WKO $n=3$. The data are representative of $(\mathbf{b}, \mathbf{d})$ three and $(\mathbf{c}, \mathbf{e})$ two separate experiments. ${ }^{\star} P<0.05 ;{ }^{\star \star} P<0.01$ as calculated by the unpaired Student's $t$-test. WT, wild type; WKO, WASp KO.

KO DCs (Fig. 7a). Wild-type CD8 ${ }^{+}$DCs had high expression of Rac2 that co-localized with the phagocytosed bead together with the NADPH component gp91phox (Fig. 7a,b, upper left image; Supplementary Fig. 9a-c). Wild-type CD8 ${ }^{-}$DCs had less Rac2 expression and did not co-localize Rac2 around the bead (Fig. 7a,b, lower left image; Supplementary Fig. 9a-c) ${ }^{21}$. WASp $\mathrm{KO} C \mathrm{CD}{ }^{+}$DCs showed similar expression and co-localization of Rac2 when compared with wild-type $\mathrm{CD}^{+}$DCs (Fig. 7a,b, upper right image; Supplementary Fig. 9a-c). The phenotype of
WASp KO $\mathrm{CD}^{-}$DCs was strikingly similar to wild-type CD8 ${ }^{+}$DCs with increased expression of Rac2 and increased co-localization of Rac2 and gp91phox to the phagocytosed bead (Fig. 7a,b, lower right image; Supplementary Fig. 9a-c). To quantify Rac1/2 activity, we measured active GTP-bound Rac1/2 in protein lysates of DCs incubated with ovalbumincoated beads. Wild-type CD8 ${ }^{+}$DCs had lower GTP-Rac1/2 when compared with WASp KO CD8 ${ }^{+}$DCs (Fig. 7c). When compared with wild-type CD8 ${ }^{-}$DCs, WASp KO CD8 ${ }^{-}$DCs 
a
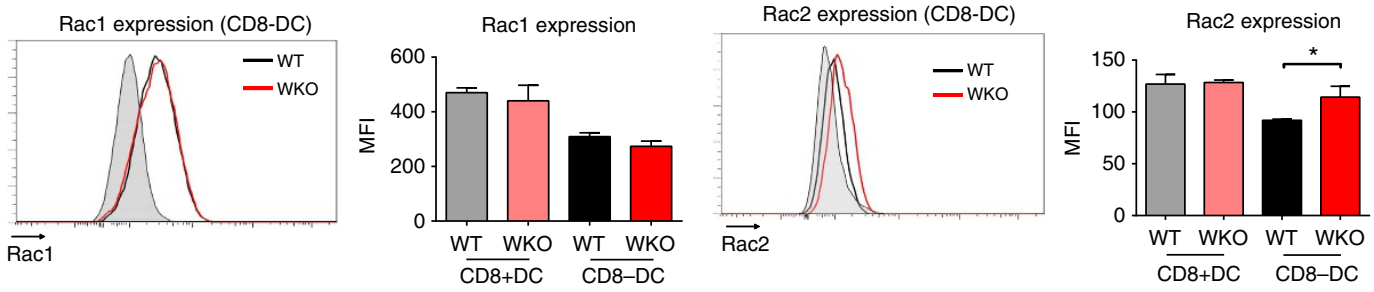

b
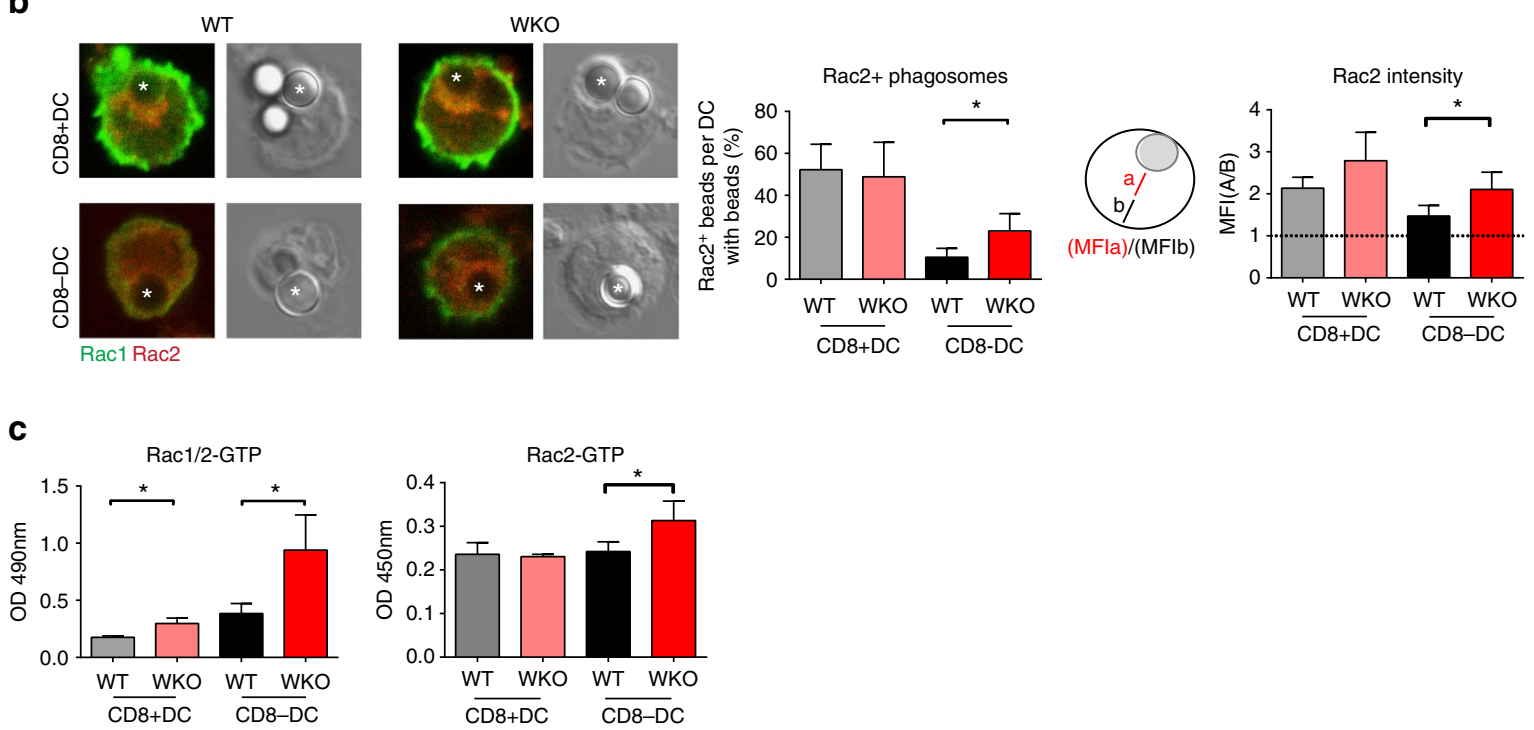

d
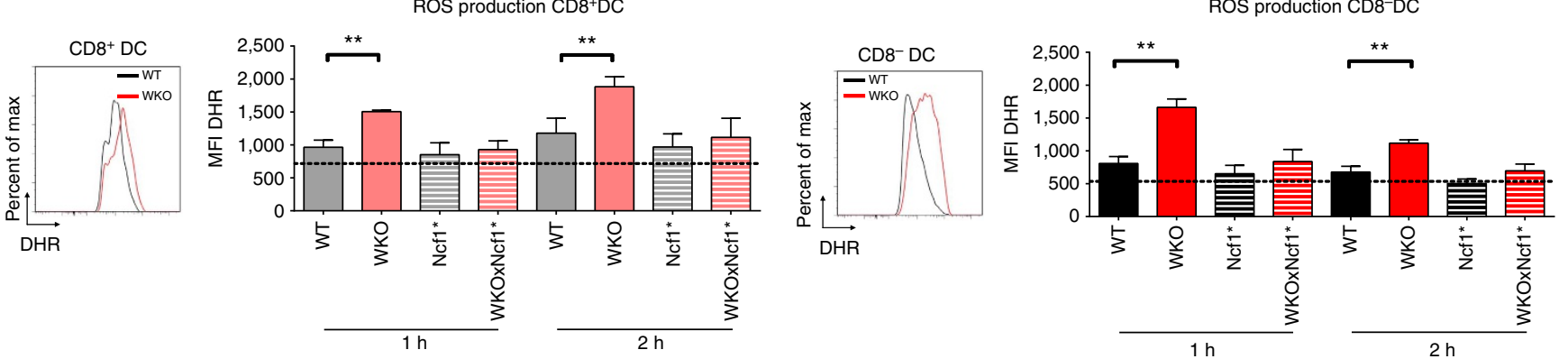

Figure 7 | WASp KO CD8 ${ }^{-}$DCs activate Rac2 and ROS production. (a) Rac1/2 expression. Wild-type and WASp KO CD8 ${ }^{+}$and CD8 ${ }^{-}$DCs from mice on C57Bl/ 6 background were stained intracellularly with anti-Rac1 and anti-Rac2 antibodies and analysed by flow cytometry. Bar represents mean \pm s.d. of WT $n=3$; WKO $n=3$. (b) Rac1/2 localization. DCs were incubated with ovalbumin-coated beads for $2 \mathrm{~h}$ to allow phagocytosis, transferred to fibronectin-coated glass and stained for Rac1-FITC (green) and Rac2-Alexa555 (red) antibodies and analysed by confocal microscopy. Both panels show Rac1 and Rac2 staining to the left and bright field to the right, with the phagocytosed bead marked with an asterisk. (Left panel) Rac2 co-localization with the phagosome was calculated as: [(beads with Rac2)/(cells with beads)] $\times 100$. Bars represent mean \pm s.d. of 3-4 mice; 7-16 pictures with total 19-119 cells per mouse. (right panel) The MFI from the middle of the cell towards the bead (a) or in the opposite direction (b) was measured using the Image J software. The (MFI a/MFI b) is shown as Rac2 intensity around the bead. Bars represent mean \pm s.d. of 3-4 mice; 3-4 pictures with total 11-21 cells per mouse. (c) Rac1/2 activity. Quantification of active GTP-bound Rac1/2 and GTP-bound Rac2. Bars represent mean \pm s.d. of 3-6 mice. (d) NADPH induced ROS production. DCs from wild type, WASp KO, Ncf1*, and WASp KO $\times \mathrm{Ncf1}^{\star}$ mice on $\mathrm{C} 57 \mathrm{BI} / 6$ background were enriched and incubated with DHR-coated beads for $1-2 \mathrm{~h}$ and analysed by flow cytometry for ROS production. The dotted line indicates background DHR intensity upon DPI treatment. The data in (a) are representative of three and (b-d) of two separate experiments. ${ }^{\star} P<0.05$; ${ }^{\star \star} P<0.01$ as calculated by the unpaired Student's $t$-test. Scale bar, $5 \mu$ m. MFI, mean fluorescence intensity; WT, wild type; WKO, WASp KO.

had higher quantity of active GTP-bound Rac1/2 (Fig. 7c). We next quantified Rac2 activity specifically and found that WASp KO CD8 ${ }^{-}$DC had the highest quantity of active GTP-bound Rac2 when compared with wild-type CD8 ${ }^{-}$DCs, and wild-type and WASp KO CD8 ${ }^{+}$DCs (Fig. 7c).

Because Rac2 activity is linked to the assembly of the NADPH complex that directly regulates the production of reactive oxygen species (ROS), we measured $\mathrm{ROS}$ in $\mathrm{CD}^{+}$and $\mathrm{CD} 8^{-}$DCs. Enriched DCs from the spleen were incubated with beads coated with dihydrorhodamine 123 (DHR) that emits fluorescence in the presence of ROS. $\mathrm{CD}^{+}{ }^{+}$and CD8 ${ }^{-}$DCs from WASp KO mice showed increased ROS production at 1 and $2 \mathrm{~h}$ when compared with corresponding DCs in wild-type mice (Fig. 7d). To confirm that the increased DHR signal was due to increased ROS, DCs 
a

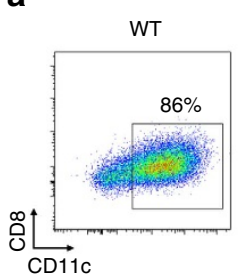

d

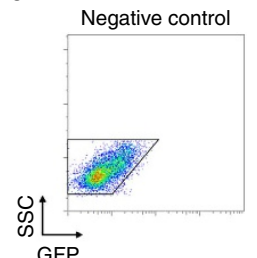

WASpWT
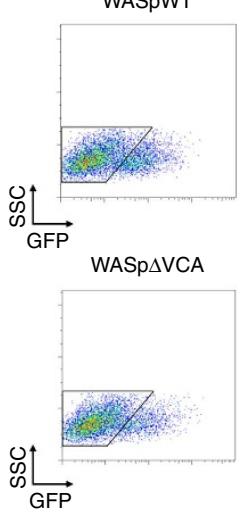

WKO

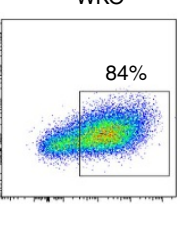

e

pHrodo ${ }^{\text {hi }}$ WASpWT

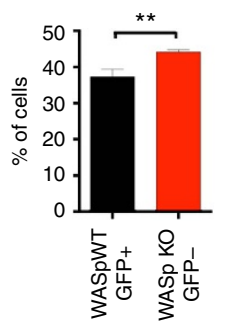

pHrodo ${ }^{\text {hi }}$ WASp $\triangle$ VCA

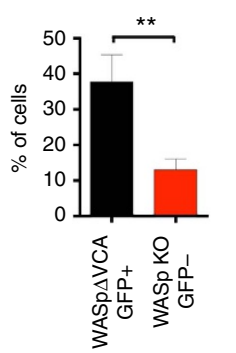

b

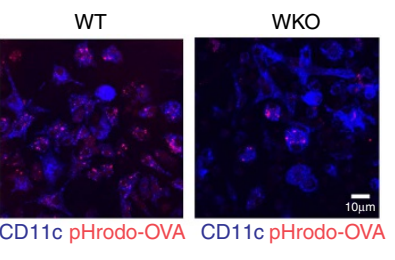

f
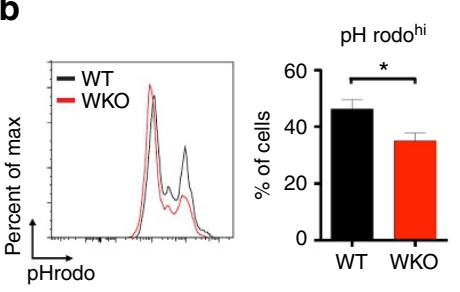

C

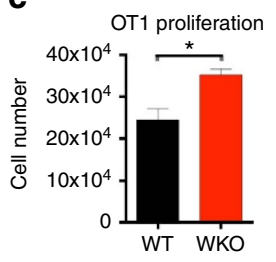

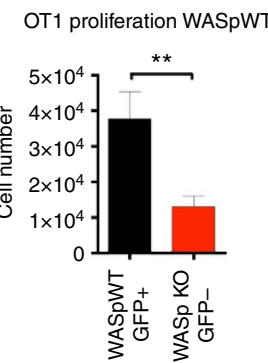

OT1 proliferation WASp $\Delta$ VCA

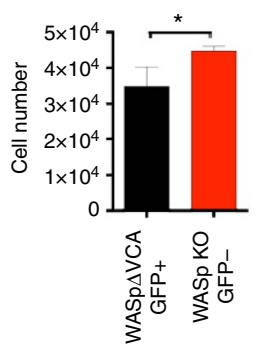

Figure 8 | WASp and the WASp-VCA domain in cross-presentation. (a-c) Wild-type and WASp KO BM DCs from mice on C57BI/6 background were analysed for capacity to acidify $\mathrm{pH}$ rodo-ovalbumin and induce proliferation of OT-I (V $\left.55.1 / 5.2^{+}\right) \mathrm{CD}^{+}$T cells. (d-f) Wild-type BM DCs at day 6 of culture were treated with CK666 to inhibit activity of the Arp2/3 complex or treated with $\alpha$-amanitin to inhibit polymerase II gene transcription. $(\mathbf{g}, \mathbf{h})$ WASp KO BM DCs at day 6 of culture were Amaxa transfected with wild-type WASp (GFP-WASpWT) or WASp lacking the VCA domain (GFP-WASp $\triangle$ VCA) and sorted into GFP ${ }^{+}$and GFP ${ }^{-}$cells $6 \mathrm{~h}$ after transfection. (a) Expression of CD11c and CD8 on BM DCs at day 6 of culture and analysis of acidification using uptake of soluble $\mathrm{pH}$ rodo-ovalbumin and confocal microscopy. (b,e,h) DCs were incubated with $\mathrm{pH}$ rodo-ovalbumin-coated beads and gated for DCs that had taken up one bead and $\mathrm{pH}$ rodo intensity was analysed by flow cytometry. (c,f,i) DCs were incubated with 0.5 mg ml ${ }^{-1}$ soluble ovalbumin and co-cultured with OT-I $\left(\mathrm{V} \beta 5.1 / 5.2^{+}\right) \mathrm{CD}^{+}{ }^{+}$T cells, and proliferation was assessed as total number of OT-I CD8 ${ }^{+} \mathrm{T}_{\text {cells }}$ by flow cytometry. (d) Wild-type BM DCs were treated for $6 \mathrm{~h}$ with CK666 to inhibit Arp2/3 activity and $\alpha$-amanitin to inhibit RNA polymerase II transcription. Note the drop in polymerized actin measured using phalloidin upon CK666 treatment and the reduced expression of cyclin A2 upon $\alpha$-amanitin treatment. (g) Gating strategy for sorting of GFP ${ }^{+}$and GFP ${ }^{-}$WASp KO BM DCs. Negative control indicates non-transfected cells. The data in (a-c) are representative of three and $(\mathbf{d}-\mathbf{h})$ of two separate experiments. ${ }^{\star} P<0.05 ;{ }^{\star} P<0.01$ as calculated by the unpaired Student's $t$-test. Scale bar, $10 \mu \mathrm{m}$. WASp $\triangle$ VCA, WASp lacking the verprolin-cofilin-acidic domain; WT, wild type; WKO, WASp KO.

were pre-treated with diphenyleneiodonium (DPI) that inhibits ROS production followed by incubation with DHR-coated beads. In the presence of DPI, the DHR signal was quenched in all DCs (indicated as dotted line in Fig. 7d). To understand if the observed increase in ROS production was directly caused by the NADPH oxidase activity, WASp KO mice were bred to $\mathrm{Ncfl}^{\mathrm{m} 1 \mathrm{~J} / \mathrm{ml}}$ mice that have reduced NADPH oxidase activity ${ }^{37}$, herein referred to as $\mathrm{Ncfl}^{\star}$ mice. WASp $\mathrm{KO} \times \mathrm{Ncfl}^{*}$ mice showed abolished ROS production in $\mathrm{CD} 8{ }^{+}$and $\mathrm{CD} 8{ }^{-} \mathrm{DCs}$ and reached the DHR intensity of wild-type $\mathrm{CD} 8^{+}$and $\mathrm{CD} 8^{-} \mathrm{DCs}$ (Fig. 7d). This suggests that increased ROS production in WASp $\mathrm{KO}$ DCs is dependent on a functional NADPH oxidase. Moreover, reduced NADPH activity in WASp $\mathrm{KO} \times \mathrm{Ncfl}^{*}$ $\mathrm{CD}^{-}$DCs restored the capacity to acidify phagosomes to $\mathrm{pH}$ 3-5 as measured by beads coated with $\mathrm{pH}$ rodo-ovalbumin (Supplementary Fig. 10). Together, our data shows that WASp $\mathrm{KO} \mathrm{CD}^{-}{ }^{-}$DCs adapt to a CD8 ${ }^{+}$DC phenotype with increased expression of Rac2 that co-localizes with the phagosome and induces elevated ROS production.
WASp and the WASp-VCA domain in cross-presentation. To address if WASp directly reduces cross-presentation in DCs, we used the fact that bone marrow (BM)-derived DCs almost exclusively consists of $\mathrm{CD} 11 \mathrm{c}^{+} \mathrm{CD} 8^{-}$DCs. BM-derived DCs from wild-type and WASp KO mice showed similar proportion of CD11c ${ }^{+} \mathrm{CD}^{-}$DCs (Fig. 8a). Similar to WASp KO spleen CD8 ${ }^{-}$DCs, WASp KO BM DCs had reduced capacity to acidify antigen and induced increased proliferation of OT-I CD8 ${ }^{+}$ $\mathrm{T}$ cells when compared with wild-type BM DCs (Fig. 8b,c). To test if re-expression of WASp would reduce cross-presentation, WASp KO BM DCs were transfected with GFP-WASpWT and $\mathrm{GFP}^{+}$and $\mathrm{GFP}^{-}$cells were sorted after $6 \mathrm{~h}$ (Fig. 8d). WASp KO BM DCs expressing GFP-WASpWT showed increased acidification and lower induction OT-I CD8 ${ }^{+}$T-cell proliferation when compared with $\mathrm{GFP}^{-}$WASp KO BM DCs (Fig. 8e,f). Finally, we tested if the WASp-VCA domain was required to dampen cross-presentation. WASp KO BM DCs expressing GFP-WASp $\triangle$ VCA showed increased acidification and lower induction OT-I CD8 ${ }^{+}$T-cell proliferation when compared with 
$\mathrm{GFP}^{-}$WASp KO BM DCs (Fig. 8e,f). Together, this data suggests that WASp directly reduced cross-presentation in $\mathrm{CD} 8^{-}$DCs in a process independent of the WASp-VCA domain.

\section{Discussion}

Studies of WAS patient cells and WASp-deficient mice have provided critical insights into the role of cell trafficking and cell-to-cell communication during an immune response ${ }^{1-3}$. Decreased migratory or cell-to-cell interaction responses in WASp-deficient cells have been interpreted to mean that WASp directly regulates these responses in WASp-sufficient cells. The results presented in the current study provide an alternative explanation. We provide evidence for that WASp deficiency skews intracellular signalling to Rac2 activation that locally maintains a near neutral $\mathrm{pH}$ of endosomes and phagosomes, necessary for cross-presentation. We propose that deletion of key proteins, such as WASp, in patients and mice may induce alternative signalling pathways for cell survival and function that leads to altered biological responses.

WASp serves an important role in the immunological synapse between $\mathrm{DCs}$ and $\mathrm{CD} 4{ }^{+} \mathrm{T}$ cells. WASp $\mathrm{KO} \mathrm{CD}^{+}{ }^{+} \mathrm{T}$ cells display normal immunological synapse formation but are unable to reform the immunological synapse after each migration phase $^{38}$. At the DC side of the synapse, WASp KO bone marrowderived DCs form less stable interactions with ovalbumin-specific wild-type $\mathrm{CD}^{+}{ }^{+} \mathrm{T}$ cells in vitro resulting in decreased T-cell activation ${ }^{39}$. The role of WASp in CD8 ${ }^{+}$DCs has been addressed by direct targeting of ovalbumin to the DEC205 receptor, uniquely expressed on $\mathrm{CD} 8{ }^{+}$DCs. Using this approach, wildtype $\mathrm{CD} 8{ }^{+}$DCs induced long-lasting contacts with ovalbuminspecific wild-type $\mathrm{CD} 8{ }^{+} \mathrm{T}$ cells in vivo, while WASp KO CD8 ${ }^{+}$ DCs formed much shorter contacts, suggesting decreased activation of $\mathrm{CD}^{+}{ }^{+} \mathrm{T}$ cells ${ }^{13}$. However, this study did not distinguish between changes in uptake of ovalbumin complexed with anti-DEC205 antibodies by WASp $\mathrm{KO}$ CD8 ${ }^{+}$DCs and changes in presentation of MHC class I-ovalbumin peptides by WASp KO CD8 ${ }^{+} \mathrm{DCs}^{13}$. In the present study we show that both WASp KO CD8 ${ }^{+}$and $\mathrm{CD}^{-}$DCs had reduced capacity to take up IgG-ovalbumin immune complexes via $\mathrm{Fc}$ receptors, whereas uptake of soluble ovalbumin was similar to wild-type DCs. In vivo, serial brief contacts (min) between antigen-presenting DCs and $\mathrm{CD} 8{ }^{+} \mathrm{T}$ cells induce early $\mathrm{CD} 8{ }^{+} \mathrm{T}$-cell activation, proliferation, and differentiation into effector cytotoxic $\mathrm{T}$ cells ${ }^{40}$. However, long-lasting contacts (hours) are needed to form CD8 ${ }^{+}$ memory cells in response to antigen ${ }^{40}$. WASp KO CD8 ${ }^{+}$DCs form immune synapses with $\mathrm{CD} 8^{+} \mathrm{T}$ cells that are short-lived in vivo ${ }^{13}$, and we show in the present study that WASp KO $\mathrm{CD}^{+}{ }^{+}$and $\mathrm{CD} 8{ }^{-}$DCs formed immune synapses in vitro leading to increased activation and proliferation of $\mathrm{CD} 8{ }^{+} \mathrm{T}$ cells. Upon $L$. major infection, we showed that despite lower number of $\mathrm{CD}{ }^{+}$DCs with capacity to cross-present antigen in the dLNs, WASp KO mice had increased activation of dLNs CD8 ${ }^{+} \mathrm{T}$ cells. Moreover, we detected a consistent increase in $\mathrm{CD} 8{ }^{+} \mathrm{T}$ cells over $\mathrm{CD}^{+}{ }^{+} \mathrm{T}$ cells in secondary lymphoid organs of WASp KO mice irrespective of inflammatory challenge. This finding suggested that the milieu in WASp $\mathrm{KO}$ mice favors $\mathrm{CD}^{+}{ }^{+}$T-cell homoeostasis. However, WASp $\mathrm{KO} \mathrm{CD}^{+} \mathrm{T}$ cells fail to respond efficiently when specific antigens are presented during viral infections as shown by other groups ${ }^{25,26,41}$. An explanation for these seemingly contradictory findings is that polyclonal activation of $\mathrm{CD}^{+} \mathrm{T}$ cells in WASp $\mathrm{KO}$ mice impedes the expansion of antigen-specific $\mathrm{CD} 8{ }^{+} \mathrm{T}$ cells during viral infection. On the basis of the previous studies and the findings in the present study, we propose that downregulation of crosspresentation by WASp may be an active process that is essential to prevent over-activation of $\mathrm{CD} 8{ }^{+} \mathrm{T}$ cells.
During contact eczema, activated effector $\mathrm{CD} 8{ }^{+} \mathrm{T}$ cells are recruited into the skin where they initiate the inflammatory cascade by inducing apoptosis of keratinocytes ${ }^{42}$. Allergencarrying Langerhans cells induce tolerance upon migration to the dLNs where allergen-specific $\mathrm{CD} 8^{+} \mathrm{T}$ cells are deleted and regulatory $\mathrm{T}$ cells activated ${ }^{43}$. In the present study, WASp KO mice challenged with Der $\mathrm{p} 2$ had increased accumulation of DCs in the dermis including the $\mathrm{CD}_{11 \mathrm{c}^{+}} \mathrm{EpCAM}^{-}$Langerin ${ }^{-} \mathrm{DCs}$ that can cross-present antigens. Using L. major infection, we detected fewer migratory MHC class $\mathrm{II}^{\text {high }}$ and $\mathrm{CD} 103^{+}$DCs in the dLNs in WASp KO mice. Moreover, we found increased expansion of WASp $\mathrm{KO} \mathrm{CD}^{+}{ }^{+} \mathrm{T}$ cells that were prone to produce IFN $\gamma$ both in vivo and in vitro. A unifying hypothesis is that skin pathology in WASp deficiency may result from decreased egress of Langerhans cells and dermal DCs from the skin, increased activation of $\mathrm{CD} 8{ }^{+} \mathrm{T}$ cells with high capacity to producing IFN $\gamma$ in the skin and dLNs, and decreased suppressive function of WASp KO regulatory $\mathrm{T}$ cells ${ }^{5-8}$. Local accumulation of DCs in the dermis, as we show in the present study, with capacity to cross-present antigen and activate $\mathrm{CD} 8^{+} \mathrm{T}$ cells would worsen this vicious cycle of $\mathrm{CD} 8{ }^{+} \mathrm{T}$-cell activation in WASp KO mice.

Our data from re-expression of WASp in WASp KO BM-derived DCs suggests that WASp directly reduced cross-presentation in $\mathrm{CD}^{-}$DCs in a process independent of the WASp-VCA domain. The WASp-VCA domain is also dispensable for WASp activity in T-cell receptor-mediated transcriptional activation ${ }^{44,45}$. Future studies are needed to address what part of WASp that is important for antigen processing and presentation. The WASp family of proteins have redundant and unique activities within the cell. N-WASp activity can compensate for critical functions of WASp during lymphocyte development since deletion of both WASp and $\mathrm{N}$-WASp in B or T cells leads to severely compromised development and function ${ }^{46,47}$. Another example of such compensatory mechanism comes from studies of WASp KO NK cells. Treatment with IL-2 restores normal cytotoxicity of WASp KO NK cells by increased activation of the WASp-family protein WAVE2 (ref. 48). We have now identified another such compensatory mechanism in which WASp KO CD8 ${ }^{-}$DCs adapt to a $\mathrm{CD}^{+}$DCs phenotype by increasing Rac2 expression and localizing Rac2 to phagosomal membranes. Importantly, $\mathrm{CD} 8^{-}$ DCs constitutes up to $40 \%$ of DCs in the spleen, as compared with $10 \% \mathrm{CD}^{+} \mathrm{DCs}$, and in the setting of wild-type $\mathrm{T}$ cells in DC/cWKO mice, WASp KO DCs induced marked expansion of $\mathrm{CD}^{+}{ }^{+} \mathrm{T}$ cells. While WASp-deficient $\mathrm{CD}^{+} \mathrm{T}$ cells are inherently hyporesponsive ${ }^{49-52}$, recent studies raises an emerging view in which WASp deficiency affects specific cells differently. In fact, WASp deficiency in plasmacytoid DCs ${ }^{53}$, $\mathrm{B}$ cells $\mathrm{s}^{35,54-56}$ and DC-mediated activation of CD8 ${ }^{+} \mathrm{T}$ cells (this study) induce hyper-responsive cells that become subjected to cellular exhaustion. Our data has implications for the treatment of WAS patients and raises concerns for those patients that have limited myeloid reconstitution and normal T-cell reconstitution after BM transplantation and gene therapy ${ }^{57-59}$.

\section{Methods}

Mice. All mice were bred and maintained in the same room at the animal facility at the Department of Microbiology, Tumor and Cell Biology, Karolinska Institutet, under specific pathogen-free conditions. WASp KO mice on $\mathrm{C} 57 \mathrm{Bl} / 6$ and $\mathrm{Balb} / \mathrm{c}$ background were backcrossed for at least nine generations. Balb/c, C57Bl/6, WASp KO Balb/c, WASp KO C57BL/6, DC/cWKO C57BL/6, OT-I Rag1 ${ }^{-1}{ }^{-}$C57BL/6, OT-II C57BL/6, C57BL/6 J-Ncf1 ${ }^{\mathrm{mlJ} / \mathrm{mlJ}}$ (referred as $\mathrm{Ncfl}^{*}$ in the text), WASp KO $\mathrm{C} 57 \mathrm{BL} / 6 \times \mathrm{C} 57 \mathrm{BL} / 6 \mathrm{~J}-\mathrm{Ncf} 1^{\mathrm{m} 1 \mathrm{~J} / \mathrm{mlJ}}$ mice (referred as WASp $\mathrm{KO} \times \mathrm{Ncfl}^{*}$ in the text) were used at 6-13 weeks of age. The DC/cWKO colony was maintained by breeding WASp ${ }^{\mathrm{fl} / \mathrm{fl}} \mathrm{CD} 11 \mathrm{c}^{\mathrm{wt} / \mathrm{wt}}$ females to WASp ${ }^{\mathrm{fl} / \mathrm{y}} \mathrm{CD} 11 \mathrm{c}^{\mathrm{cre} / \mathrm{wt}}$ males or WASp ${ }^{\mathrm{fl} / \mathrm{fl}} \mathrm{CD} 11 \mathrm{c}^{\mathrm{cre} / \mathrm{wt}}$ females to WASp ${ }^{\mathrm{fl} / \mathrm{y}} \mathrm{CD} 11 \mathrm{c}^{\mathrm{wt} / \mathrm{wt}}$ males. C57BL/6 J-Ncf1 ${ }^{\mathrm{ml} / \mathrm{m} / \mathrm{J}}$ 
mice were purchased from Jackson and backcrossed to WASp KO C57BL/6 mice to generate WASp $\mathrm{KO} \times \mathrm{Ncfl}^{\star}$ homozygous mice. All wild-type mice were littermate controls from heterozygous breedings with the respective gene-targeted allele and genotyped before use. Animal experiments were performed after approval from the local ethical committee (the north Stockholm district court).

Der $\mathbf{p} 2$ challenge protocol and in vivo migration. Wild-type and WASp KO $\mathrm{Balb} / \mathrm{c}$ mice were challenged with Der $\mathrm{p} 2$ (ref. 29). Briefly, mice were shaved on the back and patched $3 \times 4$ days with $50 \mu \mathrm{g}$ of Der p 2 in $100 \mu \mathrm{l}$ of PBS on $1 \mathrm{~cm}^{2}$ of shaved skin and sacrificed at day 50 . We have used two different preparations of Der $\mathrm{p} 2$ with $<35 \mathrm{ng}$ of lipopolysaccharide per $\mathrm{mg}$ protein and obtained similar results for the in vivo and in vitro experiments using both batches. Unchallanged mice were not patched or shaved. For epidermal sheets, full-thickness skin from back was incubated for $90 \mathrm{~min}$ at $37^{\circ} \mathrm{C}$ in a PBS solution plus $2.5 \mathrm{mg} \mathrm{ml}^{-1}$ dispase (Invitrogen). Single cell suspensions for dLN and spleen were prepared by incubating SPL and dLNs in $1 \%$ serum complete medium plus $0.5 \mathrm{mg} \mathrm{ml}^{-1}$ collagenase D for $30-45 \mathrm{~min}$ or plus $1.5 \mathrm{mg} \mathrm{ml}^{-1}$ collagenase $\mathrm{D}$ for $1.5 \mathrm{~h}$. Ears were further processed using a BD Medimachine system (BD Biosciences) for tissue grinding. Single cell suspensions from spleen were cultured in complete RPMI medium with Der p 2 or PMA and ionomicin (Sigma), and incubated at $37^{\circ} \mathrm{C}$ for $4-48 \mathrm{~h}$. Golgiplug (BD Biosciences) was added to the last $4 \mathrm{~h}$ of incubation to all cell cultures. For in vivo migration, Aldara 5\% cream (imiquimod; Meda) was applied epicutaneously on ears of anesthetized mice and let dry to induce dendritic cell maturation and migration to the dLNs. Draining LNs were treated with collagenase $\mathrm{D}$ as described above for single cell suspension and analyzed by FACS.

L. major infection. L. major strain Fvl (MHOM/IL/80/FN) was grown at $25^{\circ} \mathrm{C}$ to stationary phase in complete M199 supplemented with $20 \%$ foetal calf serum (parasite growth medium). Parasites were enriched for infectious metacyclic promastigotes by Ficoll 400 gradient separation ${ }^{33}$. Estimation of parasite number was determined by serial 1:2 dilutions of tissue homogenates in parasite growth medium. The number of viable parasites in each sample was calculated based on the highest dilution at which promastigotes could be grown out after 4-5 days of incubation at $25^{\circ} \mathrm{C}$. The limitation of the assay was 10 parasites per ear and 20 parasites per dLN. Wild-type and WASp KO Balb/c mice were infected intradermally in both ears with $4 \times 10^{4}$ metacyclic $L$. major promastigotes in $10 \mu \mathrm{l}$ DMEM. Control mice received sham injections of DMEM. Progression of lesion development was measured weekly using a digital veiner calliper and indicated as diameter of the lesion. After 2 or 6 weeks mice were euthanized, and ears and retromaxillar dLNs were removed. Single cell suspensions were prepared by incubating ears and dLNs in $1 \%$ serum complete medium plus $1.5 \mathrm{mg} \mathrm{ml}^{-1}$ collagenase D for $1.5 \mathrm{~h}$ or plus $0.5 \mathrm{mg} \mathrm{ml}^{-1}$ collagenase D for $30-45 \mathrm{~min}$, respectively. Ears were further processed using a BD Medimachine system (BD Biosciences) for tissue grinding. To measure cytokine production, single cell suspensions from retromaxillar dLNs were cultured with PMA and ionomicin (Sigma) and golgiplug (Becton Dickenson) for $4 \mathrm{~h}$

Antibodies. The following antibodies were used for flow cytometry and/or immunohistochemistry: CD3-PE/Cy7 1:100 (557851), CD8 $\alpha$-PerCP/Cy5.5 1:100 (100734), CD8 $\alpha$-Alexa647 1:200 (557682), CD11c-biotin 1:200 (553800), CD45-APC/Cy7 1:200 (557659), CD45-PerCP/Cy5.5 1:200 (103236), CD62L-FITC 1:100 (553150), IgG1-FITC 1:100 (553443), IgE-biotin 1:200 (553419), PDL1-PE 1:200 (558091), B220-V500 1:200 (561227), CD3-V500 1:200 (560773), V $\alpha 2$-FITC 1:100 (553288), Vß5.1/5.2-PE 1:200 (553190), CD86-FITC 1:200 (553691), CD69-PE 1:200 (553237; BD Biosciences), CD4-eFluor450 1:100 (48-0042-82), CD4-APC 1:200 (100516), CD8ß-biotin 1:200 (13-0083-81), CD103-FITC 1:200 (121420), F4/80-eFluor450 1:100 (48-4801-82), CD11c-PE/Cy7 1:100 (117318), MHCI-eFluor450 (H2-Kb) 1:100 (48-5958-80), IFN $\gamma$-PerCP/Cy5.5 1:100 (505822), IL-17A-FITC 1:100 (11-7177-81; eBioscience), Strepavidin-alexa555 1:1000 (S32355) (ThermoFisher), 7AAD $7 \mu \mathrm{l}$ per $200 \mu \mathrm{l}$ of cell volume (51-2359KC) (BD Pharmingen), Live/Dead Fixable Vivid-nearIR 1:500 (L10119), live/dead-AmCyan 1:400 (L34966) (Invitrogen), B220-APC 1:400 (103212), B220-Pacific Blue 1:200 (103227), EpCAM-APC 1:200 (118214), CD11b-PerCP/Cy5.5 1:100 (101228), CD4-FITC 1:100 (100510), MHCII-APC (I-A/I-E) 1:400 (107614), TCR $\beta$-APC 1:200 (109212), B220-APC/Cy7 1:200 (103224), Fc $\gamma$ RI 1:100 (139303), Fc $\gamma$ RII/III 1:100 (101308), gp91phox 1:200 (650102), CD44-PE 1:400 (103008) (BioLegend), CD19-APC 1:200 (LS-C148489) (LSBio), CD207(langerin)-FITC 1:400 (DDX0362A488-100) (Dendritics), racl-FITC 1:50 (bs-4186R-FITC), rac2-Alexa555 1:50 (bs-6153R-A555) (BIOSS), biotin-XX phalloidin 1:1000 (B7474) (Invitrogen), $\gamma$-tubulin 1:200 (072M4808) (Sigma), FcRn 1:100 (AF6775) (R\&D Systems), and cyclin A2 1:200 (ab38) (Abcam), aWASp 1:200 (sc-13139), aGAPDH 1:200 (sc-25778) (Santa Cruz).

Histology and flow cytometry. For Der p 2-challenged mice, the skin within the 1 $\mathrm{cm}^{2}$ square shaved and treated with Der $\mathrm{p} 2$ was macroscopically examined, and $4 \mathrm{~mm}^{2}$ punch biopsies were taken from areas of red thickened skin for sections and image analysis. Skin tissues were snap frozen in Tissue-Tek OCT (Bio-Optica). Sections $(8-10 \mu \mathrm{m})$ were cut, air dried overnight and fixed in cold acetone. Hematoxylin and eosin staining was performed using standard protocol and immunohistochemistry ${ }^{46}$. Images were acquired using a Leica DM IRBE confocal laser scanning microscope (Leica Microsystems) equipped with 1 argon and 2 HeNe lasers, using an HC PL APO lens at $20 \times / 0.70$ CS and $63 \times / 1.32 \mathrm{IMM}$ CORR oil and $90 \%$ glycerol (MP Biomedicals). Images were processed with Adobe Photoshop CS4 Version 11.0.2 (Adobe Systems) and ImageJ software. Histological examination and analysis of skin sections were performed blindly where the identity of the section was unknown to the observer. The epidermis thickness values represent the picture with the highest measured thickness of each mouse. When counting cells on images, co-localization of two fluorochromes was based on colour intensity between 150-255 pixel co-localization of red, green, and/or blue using the ImageJ software. To quantify the cells per area on epidermis or in the dermis of whole-skin sections, the cells were counted and areas measured using ImageJ. For flow cytometry analysis, single cell suspensions from organs were prepared and erythrocytes lysed with ACK buffer. Cells were immunolabelled and acquired using a FACS Aria or LSR Fortessa (Becton Dickenson). Analyses were made using FlowJo software (version 7.2.5 TreeStar Inc.).

Immune synapse and cross-presentation assay. For immune synapse experiments, the splenic DC population was expanded by subcutaneous injection of $1 \times 10^{6}$ Flt3-ligand B16 melanoma cells and DCs purified after 7-10 days with the $\mathrm{CD}^{+}{ }^{+} \mathrm{DC}$ isolation kit followed by CD11c positive selection (Miltenyi Biotec). $\mathrm{CD}^{+}$and $\mathrm{CD} 88^{-}$DCs were pulsed with ovalbumin overnight and incubated with OT-I CD8 ${ }^{+} \mathrm{T}$ cells for $2 \mathrm{~h}$. Cells were transferred to fibronectin-coated slides, fixed and stained with $\gamma$-ubulin (green) and actin (red). For cross-presentation assays, $\mathrm{CD}^{+}{ }^{+}$DCs and $\mathrm{CD} 8{ }^{-}$DCs from wild-type and WASp KO C57Bl/6 mice were isolated by incubating spleens with complete medium plus $1 \%$ serum and $0.5 \mathrm{mg} \mathrm{ml}^{-1}$ collagenase D followed by enrichment with the Dynabeads mouse DC enrichment kit (Invitrogen) and thereafter FACS sorted based on CD8 and CD11c using FACS Vantage. FACS-sorted DCs were pulsed with 16,50 and $150 \mu \mathrm{g} \mathrm{ml}^{-1}$ soluble ovalbumin, with $3 \mu \mathrm{m}$ ovalbumin-coated latex beads (Life Technologies), or with $2 \mu \mathrm{g} \mathrm{ml}^{-1}$ SIINFEKL peptide overnight. To examine cross-presentation of immune complexes (ICs), sorted DCs were incubated with pre-formed ICs of antiTNP-IgG1 and TNP(5)-OVA at $0.25,1.25$ and $6.25 \mu \mathrm{g} \mathrm{ml}^{-1}$ final concentrations. OT-I CD8 ${ }^{+}$T cells from spleen were sorted by negative selection using the CD8 $\alpha$ T-cell isolation kit II (Miltenyi Biotec), with a purity of more than $95 \%$, and labelled with $2 \mu \mathrm{M}$ CFSE (Invitrogen). Sorted DCs were co-cultured with OT-I $\mathrm{CD}^{+} \mathrm{T}$ cells at 1:10 DC:T-cell ratio and analyzed by FACS after $72 \mathrm{~h}$. For the ${ }^{3} \mathrm{H}$-thymidine incorporation assay, OT-I T cells were co-cultured with $\mathrm{CD} 8{ }^{+}$or CD8 ${ }^{-}$DCs for $72 \mathrm{~h}$ and pulsed with $1 \mu \mathrm{Ci}$ of ${ }^{3} \mathrm{H}$-thymidine for the last $12 \mathrm{~h}$, collected and scintillation measured.

Antigen processing and ROS production assay. The splenic DC population was expanded by subcutaneous injection of $1 \times 10^{6}$ Flt3-ligand B16 melanoma cells and DCs purified after 7-10 days with the CD8 ${ }^{+}$DC isolation kit followed by CD11c positive selection (Miltenyi Biotec). Enriched CD8 ${ }^{+}$DCs and CD8 ${ }^{-}$DCs were incubated with 16,50 and $150 \mu \mathrm{g} \mathrm{ml}^{-1}$ ovalbumin-Alexa594 or DQ-ovalbumin (Invitrogen) for up to $6 \mathrm{~h}$ for ovalbumin uptake and degradation, respectively. To assess acidification capacity, ovalbumin was linked to $\mathrm{pH}$-rodo according to the manufacturer's instructions (Invitrogen) and DCs were incubated with $50 \mu \mathrm{g} \mathrm{ml}^{-1}$ ovalbumin-pH rodo for $6 \mathrm{~h}$. To measure the production of ROS, the probe DHR (Life Technologies) was used. To control the amount of ovalbumin-pH rodo or DHR taken up over time by each cell, a particulate antigen assay was performed by coating $3 \mu \mathrm{m}$ latex beads (Life Technologies) to $\mathrm{pH}$ rodo-ovalbumin or DHR. DCs that took up only one bead were gated on a flow cytometer according to FSC versus SSC parameters for acidification analysis. As negative controls for acidification and for ROS production, DCs were either pre-treated with $20 \mathrm{mM}$ of $\mathrm{NH}_{4} \mathrm{Cl}$ before addition of the $\mathrm{pH}$ rodo-ovalbumin-coated beads, or with $20 \mu \mathrm{M}$ DPI before addition of the DHR-coated beads. Upon incubation, cells were stained with CD11c, MHCII and CD8 to identify CD11c ${ }^{+} \mathrm{MHCII}^{+} \mathrm{CD} 8{ }^{+} \mathrm{DC}$ and $\mathrm{CD} 11 \mathrm{c}^{+}$ $\mathrm{MHCII}^{+} \mathrm{CD} 8{ }^{-}$DCs and other cells including plasmacytoid DCs, B and T cells were excluded in a dump gate using B220 and CD3. Dead cells were excluded based on positive staining for DAPI. The $\mathrm{pH}$ was measured with a slightly modified protocol described in Savina et al. ${ }^{36}$ In short, DCs were enriched using dynabeads mouse DC enrichment (Life Technologies) and incubated with NHS-ester polyamino beads coupled with $1 \mathrm{mg} \mathrm{ml}^{-1}$ FITC and $1 \mathrm{mg} \mathrm{ml}^{-1}$ Alexa647. A standard curve was performed where enriched DCs were allowed to phagocytose the beads for $30 \mathrm{~min}$. Cells were fixed with $4 \%$ paraformaldehyde, and incubated with $0.1 \%$ Triton X-100 in PBS with pH kept at 7. Afterwards DCs were submitted to PBS solutions with $\mathrm{pH}$ ranging from 5 to 8 and let incubate for a couple of minutes. Samples were immediately analysed by FACS and MFI of FITC and Alexa647 measured on $\mathrm{CD}_{11 \mathrm{c}^{+}}$-gated cells. The standard curve was obtained by calculating the ratio of 'MFI FITC/MFI Alexa647' at the corresponding pH. WT and WASp KO DCs were incubated with the same beads used for the standard curve, the MFI for FITC and Alexa647 was obtained on gated CD8 ${ }^{+} \mathrm{CD}_{11 c^{+}}$or $\mathrm{CD} 8{ }^{-} \mathrm{CD} 11 \mathrm{c}^{+}$cells (dump gate used with $\mathrm{B} 220, \mathrm{CD} 3$ and live/dead antibodies) and the $\mathrm{pH}$ calculated using the formula obtained by the standard curve. To assess uptake of immunocomplexes (ICs) DCs were enriched as above described and incubated with a 1:20 dilution of pre-formed ICs of anti-TNP-IgG1 and TNP(5)OVA at $0.25,1.25$ and $6.25 \mu \mathrm{g} \mathrm{ml}^{-1}$ final concentrations. Antigen presentation of 
DCs in the presence of ICs was determined by flow cytometry and staining of DCs with the antibody towards $\mathrm{H}-2 \mathrm{~K}^{\mathrm{b}}$-SIINFEKL (clone 25-D1.16, Biolegend).

Rac1/2 assays. The splenic DC population was expanded by subcutaneous injection of $1 \times 10^{6}$ Flt3-ligand B16 melanoma cells and DCs enriched after 7-10 days with the $\mathrm{CD}^{+}{ }^{+} \mathrm{DC}$ isolation kit followed by CD11c positive selection (Miltenyi Biotec). To determine Rac1/2 and gp91phox expression and co-localization to the phagosome, enriched CD8 ${ }^{+}$DCs and $\mathrm{CD} 8{ }^{-}$DCs were incubated with $3 \mu \mathrm{m}$ ovalbumin-coated latex beads for $2 \mathrm{~h}$ at $37^{\circ} \mathrm{C}$, transferred to glass coverslips coated with $50 \mathrm{\mu g} \mathrm{ml}^{-1}$ fibronectin (Gibco) and incubated for $1 \mathrm{~h}$ at $37^{\circ} \mathrm{C}$. Afterwards, cells were fixed with $4 \%$ paraformaldehyde, quenched with $0.1 \mathrm{M}$ glycine, permeabilized and stained intracellularly with primary antibodies for Rac1, Rac2 and gp91phox. Cells were analysed using a Zeiss LSM 780 confocal microscope equipped with a diode laser with wavelength $405 \mathrm{~nm}$, an Argon laser with wavelengths $458 / 488 / 514 \mathrm{~nm}$ DPSS $561 \mathrm{~nm}$ and a HeNe $633 \mathrm{~nm}$ laser. Pictures were acquired using a Plan-Apo $63 \times / 1.4$ oil-immersion lens and the ZEN Black 2011 software. Rac2 co-localization with the phagosome was calculated as: [(beads with Rac2)/(cells with beads) $] \times 100$. Five to 15 images per mouse were analyzed. Rac2 co-localization was further assessed by $z$-stack analysis from pictures taken with a $63 \times$ objective and a step-size of $1.3 \mu \mathrm{m}$ per picture. Pictures were compressed into one single image using ImageJ. For Rac1/2 activity, protein lysates were prepared from DCs incubated with ovalbumin-coated latex beads for $2 \mathrm{~h}$ and protein content measured and diluted to equal concentration. Active GTP-bound Rac1/2 was quantified using the G-LISA Rac1,2,3 Activation Assay Biochem Kit (Cytoskeleton). To quantify GTP-bound Rac2 a modified version of the G-LISA kit was used with an anti-Rac2 (Santa Cruz Biotechnology) detection antibody, anti-rabbit-HRP (Santa Cruz Biotechnology) secondary, and anti-goat-HRP (Santa Cruz Biotechnology) tertiary antibodies.

Transfection of BM DCs. BM cells from femur and tibia were cultured in $20 \mathrm{ng} \mathrm{ml}^{-1}$ GMCSF (Peprotech) for 6 days. For confocal microscopy, BM DCs were incubated with $0.5 \mathrm{mg} \mathrm{ml}^{-1}$ soluble ovalbumin-pH rodo for $1 \mathrm{~h}$ and analyzed by confocal microscopy after staining with anti-CD11c. For re-expression of WASp, WASp KO BM DCs were transfected with eGFP-WASpWT or eGFPWASp $\triangle$ VCA constructs ${ }^{60}$ using Amaxa transfection (Primary cell $4 \mathrm{D}$ nucleofector kit, Lonza). After $6 \mathrm{~h}, \mathrm{GFP}^{+}$and GFP ${ }^{-}$cells were FACS sorted using FACS Jazz. To assess acidification capacity, BM DCs after Amaxa transfection were incubated with ovalbumin-pH rodo beads for $30 \mathrm{~min}$ and $\mathrm{pH}$ rodo fluorescence determined in cells that had taken up one bead. To determine proliferation of OT-I CD8 ${ }^{+}$ $\mathrm{T}$ cells, BM DCs after Amaxa transfection were incubated with $0.5 \mathrm{mg} \mathrm{ml}^{-1}$ ovalbumin and LPS overnight. BM DCs were co-cultured with OT-I CD8 ${ }^{+} \mathrm{T}$ cells at 1:10 DC:T-cell ratio and analyzed by FACS after $48 \mathrm{~h}$.

Data and statistical analysis. For comparison between wild-type and WASp KO mice, data passed the normality test and was analyzed by the unpaired Student's $t$-test using GraphPad Prism 5.0 software and a two-tailed $P$ value with $95 \%$ confidence interval was acquired. Data is shown as mean \pm s.d. and $P<0.05$ was considered significant.

Data availability. The data that support the findings of this study are available from the corresponding authors on request.

\section{References}

1. Thrasher, A. J. \& Burns, S. O. WASP: a key immunological multitasker. Nat. Rev. Immunol. 10, 182-192 (2010).

2. Bosticardo, M., Marangoni, F., Aiuti, A., Villa, A. \& Roncarolo, M. G. Recent advances in understanding the pathophysiology of Wiskott-Aldrich syndrome. Blood 113, 6288-6295 (2009).

3. Massaad, M. J., Ramesh, N. \& Geha, R. S. Wiskott-Aldrich syndrome: a comprehensive review. Ann. N. Y. Acad. Sci. 1285, 26-43 (2013).

4. Ozcan, E., Notarangelo, L. D. \& Geha, R. S. Primary immune deficiencies with aberrant IgE production. J. Allergy Clin. Immunol. 122, 1054-1062 (2008).

5. Maillard, M. H. et al. The Wiskott-Aldrich syndrome protein is required for the function of $\mathrm{CD} 4\left({ }^{+}\right) \mathrm{CD} 25\left(^{+}\right) \mathrm{Foxp} 3\left(^{+}\right)$regulatory T cells. J. Exp. Med. 204, 381-391 (2007).

6. Marangoni, F. et al. WASP regulates suppressor activity of human and murine $\mathrm{CD} 4\left({ }^{+}\right) \mathrm{CD} 25\left({ }^{+}\right) \mathrm{FOXP} 3\left({ }^{+}\right)$natural regulatory T cells. J. Exp. Med. 204, 369380 (2007).

7. Humblet-Baron, S. et al. Wiskott-Aldrich syndrome protein is required for regulatory T cell homeostasis. J. Clin. Invest. 117, 407-418 (2007).

8. Adriani, M. et al. Impaired in vitro regulatory T cell function associated with Wiskott-Aldrich syndrome. Clin. Immunol. 124, 41-48 (2007).

9. Pivniouk, V. I. et al. Impaired signaling via the high-affinity IgE receptor in Wiskott-Aldrich syndrome protein-deficient mast cells. Int. Immunol. 15, 1431-1440 (2003).

10. de Noronha, S. et al. Impaired dendritic-cell homing in vivo in the absence of Wiskott-Aldrich syndrome protein. Blood 105, 1590-1597 (2005).
11. Bouma, G., Burns, S. \& Thrasher, A. J. Impaired T-cell priming in vivo resulting from dysfunction of WASp-deficient dendritic cells. Blood 110, 4278-4284 (2007).

12. Burns, S., Thrasher, A. J., Blundell, M. P., Machesky, L. \& Jones, G. E. Configuration of human dendritic cell cytoskeleton by Rho GTPases, the WAS protein, and differentiation. Blood 98, 1142-1149 (2001).

13. Pulecio, J. et al. Expression of Wiskott-Aldrich syndrome protein in dendritic cells regulates synapse formation and activation of naive $\mathrm{CD} 8{ }^{+} \mathrm{T}$ cells. J. Immunol. 181, 1135-1142 (2008).

14. Kim, A. S., Kakalis, L. T., Abdul-Manan, N., Liu, G. A. \& Rosen, M. K. Autoinhibition and activation mechanisms of the Wiskott-Aldrich syndrome protein. Nature 404, 151-158 (2000).

15. Torres, E. \& Rosen, M. K. Contingent phosphorylation/dephosphorylation provides a mechanism of molecular memory in WASP. Mol. Cell 11, 1215-1227 (2003).

16. Machesky, L. M. \& Insall, R. H. Scar1 and the related Wiskott-Aldrich syndrome protein, WASP, regulate the actin cytoskeleton through the Arp2/3 complex. Curr. Biol. 8, 1347-1356 (1998).

17. Miki, H., Suetsugu, S. \& Takenawa, T. WAVE, a novel WASP-family protein involved in actin reorganization induced by Rac. EMBO J. 17, 6932-6941 (1998).

18. Heath, W. R. \& Carbone, F. R. Dendritic cell subsets in primary and secondary T cell responses at body surfaces. Nat. Immunol. 10, 1237-1244 (2009).

19. Bedoui, S. et al. Cross-presentation of viral and self antigens by skin-derived $\mathrm{CD} 03^{+}$dendritic cells. Nat. Immunol. 10, 488-495 (2009).

20. Joffre, O. P., Segura, E., Savina, A. \& Amigorena, S. Cross-presentation by dendritic cells. Nat. Rev. Immunol. 12, 557-569 (2012).

21. Savina, A. et al. The small GTPase Rac2 controls phagosomal alkalinization and antigen crosspresentation selectively in $\mathrm{CD} 8\left(^{+}\right)$dendritic cells. Immunity $\mathbf{3 0}$, 544-555 (2009).

22. den Haan, J. M. \& Bevan, M. J. Constitutive versus activation-dependent cross-presentation of immune complexes by $\mathrm{CD} 8\left({ }^{+}\right)$and $\mathrm{CD} 8(-)$ dendritic cells in vivo. J. Exp. Med. 196, 817-827 (2002).

23. Regnault, A. et al. Fcgamma receptor-mediated induction of dendritic cell maturation and major histocompatibility complex class I-restricted antigen presentation after immune complex internalization. J. Exp. Med. 189, 371-380 (1999).

24. Baker, K. et al. Neonatal Fc receptor for IgG (FcRn) regulates crosspresentation of IgG immune complexes by CD8-CD11b ${ }^{+}$dendritic cells. Proc. Natl Acad. Sci. USA 108, 9927-9932 (2011).

25. Lang, P. A. et al. Reduced type I interferon production by dendritic cells and weakened antiviral immunity in patients with Wiskott-Aldrich syndrome protein deficiency. J. Allergy Clin. Immunol. 131, 815-824 (2013).

26. Andreansky, S. et al. WASP- mice exhibit defective immune responses to influenza A virus, Streptococcus pneumoniae, and Mycobacterium bovis BCG. Exp. Hematol. 33, 443-451 (2005).

27. Strom, T. S., Gabbard, W., Kelly, P. F., Cunningham, J. M. \& Nienhuis, A. W Functional correction of $\mathrm{T}$ cells derived from patients with the Wiskott-Aldrich syndrome (WAS) by transduction with an oncoretroviral vector encoding the WAS protein. Gene Ther. 10, 803-809 (2003).

28. Darsow, U. et al. The prevalence of positive reactions in the atopy patch test with aeroallergens and food allergens in subjects with atopic eczema: a European multicenter study. Allergy 59, 1318-1325 (2004).

29. Lieden, A. et al. Cornulin, a marker of late epidermal differentiation, is down-regulated in eczema. Allergy 64, 304-311 (2009).

30. Huang, C. H., Kuo, I. C., Xu, H., Lee, Y. S. \& Chua, K. Y. Mite allergen induces allergic dermatitis with concomitant neurogenic inflammation in mouse. J. Invest. Dermatol. 121, 289-293 (2003).

31. Henri, S. et al. Disentangling the complexity of the skin dendritic cell network. Immunol. Cell Biol. 88, 366-375 (2010).

32. Heath, W. R. \& Carbone, F. R. The skin-resident and migratory immune system in steady state and memory: innate lymphocytes, dendritic cells and $\mathrm{T}$ cells. Nat. Immunol. 14, 978-985 (2013).

33. Nylen, S. et al. Splenic accumulation of IL-10 mRNA in T cells distinct from $\mathrm{CD} 4{ }^{+} \mathrm{CD} 25^{+}$(Foxp3) regulatory $\mathrm{T}$ cells in human visceral leishmaniasis. J. Exp. Med. 204, 805-817 (2007).

34. Nylen, S. \& Eidsmo, L. Tissue damage and immunity in cutaneous leishmaniasis. Parasite Immunol. 34, 551-561 (2012).

35. Recher, M. et al. B cell-intrinsic deficiency of the Wiskott-Aldrich syndrome protein (WASp) causes severe abnormalities of the peripheral B-cell compartment in mice. Blood 119, 2819-2828 (2012).

36. Savina, A. et al. NOX2 controls phagosomal $\mathrm{pH}$ to regulate antigen processing during crosspresentation by dendritic cells. Cell 126, 205-218 (2006).

37. Hultqvist, M. et al. Enhanced autoimmunity, arthritis, and encephalomyelitis in mice with a reduced oxidative burst due to a mutation in the Ncfl gene. Proc. Natl Acad. Sci. USA 101, 12646-12651 (2004).

38. Sims, T. N. et al. Opposing effects of PKCtheta and WASp on symmetry breaking and relocation of the immunological synapse. Cell 129, 773-785 (2007). 
39. Bouma, G. et al. Cytoskeletal remodeling mediated by WASp in dendritic cells is necessary for normal immune synapse formation and $\mathrm{T}$ cell priming. Blood 118, 2492-2501 (2011).

40. Scholer, A., Hugues, S., Boissonnas, A., Fetler, L. \& Amigorena, S. Intercellular adhesion molecule-1-dependent stable interactions between $\mathrm{T}$ cells and dendritic cells determine CD8 ${ }^{+} \mathrm{T}$ cell memory. Immunity 28, 258-270 (2008).

41. Strom, T. S. et al. Defects in T-cell-mediated immunity to influenza virus in murine Wiskott-Aldrich syndrome are corrected by oncoretroviral vectormediated gene transfer into repopulating hematopoietic cells. Blood 102, 3108-3116 (2003).

42. Akiba, H. et al. Skin inflammation during contact hypersensitivity is mediated by early recruitment of $\mathrm{CD} 8{ }^{+} \mathrm{T}$ cytotoxic 1 cells inducing keratinocyte apoptosis. J. Immunol. 168, 3079-3087 (2002).

43. Gomez de Agüero, M. et al. Langerhans cells protect from allergic contact dermatitis in mice by tolerizing $\mathrm{CD}^{+}{ }^{+} \mathrm{T}$ cells and activating Foxp3 ${ }^{+}$ regulatory T cells. J. Clin. Invest. 122, 1700-1711 (2012).

44. Silvin, C., Belisle, B. \& Abo, A. A role for Wiskott-Aldrich syndrome protein in T-cell receptor-mediated transcriptional activation independent of actin polymerization. J. Biol. Chem. 276, 21450-21457 (2001).

45. Sadhukhan, S., Sarkar, K., Taylor, M., Candotti, F. \& Vyas, Y. M. Nuclear role of WASp in gene transcription is uncoupled from its ARP2/3-dependent cytoplasmic role in actin polymerization. J. Immunol. 193, 150-160 (2014).

46. Westerberg, L. S. et al. Wiskott-Aldrich syndrome protein (WASP) and N-WASP are critical for peripheral B-cell development and function. Blood 119, 3966-3974 (2012).

47. Cotta-de-Almeida, V. et al. Wiskott-Aldrich syndrome protein (WASP) and N-WASP are critical for T cell development. Proc. Natl Acad. Sci. USA 104, 15424-15429 (2007).

48. Orange, J. S. et al. IL-2 induces a WAVE2-dependent pathway for actin reorganization that enables WASp-independent human NK cell function. J. Clin. Invest. 121, 1535-1548 (2011).

49. Snapper, S. B. et al. Wiskott-Aldrich syndrome protein-deficient mice reveal a role for WASP in T but not B cell activation. Immunity 9, 81-91 (1998).

50. Zhang, J. et al. Antigen receptor-induced activation and cytoskeletal rearrangement are impaired in Wiskott-Aldrich syndrome protein-deficient lymphocytes. J. Exp. Med. 190, 1329-1342 (1999).

51. Morales-Tirado, V. et al. Cutting edge: selective requirement for the Wiskott-Aldrich syndrome protein in cytokine, but not chemokine, secretion by $\mathrm{CD}^{+}{ }^{+} \mathrm{T}$ cells. J. Immunol. 173, 726-730 (2004).

52. Trifari, S. et al. Defective Th1 cytokine gene transcription in $\mathrm{CD}^{+}{ }^{+}$and $\mathrm{CD} 8{ }^{+}$ $\mathrm{T}$ cells from Wiskott-Aldrich syndrome patients. J. Immunol. 177, 7451-7461 (2006).

53. Prete, F. et al. Wiskott-Aldrich syndrome protein-mediated actin dynamics control type-I interferon production in plasmacytoid dendritic cells. J. Exp. Med. 210, 355-374 (2013).

54. Becker-Herman, S. et al. WASp-deficient B cells play a critical, cell-intrinsic role in triggering autoimmunity. J. Exp. Med. 208, 2033-2042 (2011).

55. Dahlberg, C. I. et al. Deletion of WASp and N-WASp in B cells cripples the germinal center response and results in production of IgM autoantibodies. J. Autoimmun. 62, 81-92 (2015)

56. Volpi, S. et al. N-WASP is required for B-cell-mediated autoimmunity in Wiskott-Aldrich syndrome. Blood 127, 216-220 (2016).

57. Aiuti, A. et al. Lentiviral hematopoietic stem cell gene therapy in patients with Wiskott-Aldrich syndrome. Science 341, 1233151 (2013).

58. Boztug, K. et al. Stem-cell gene therapy for the Wiskott-Aldrich syndrome. N. Engl. J. Med. 363, 1918-1927 (2010).
59. Griffith, L. M. et al. Primary Immune Deficiency Treatment Consortium (PIDTC) report. J. Allergy Clin. Immunol. 133, 335-347 (2014).

60. Worth, A. J. et al. Disease-associated missense mutations in the EVH1 domain disrupt intrinsic WASp function causing dysregulated actin dynamics and impaired dendritic cell migration. Blood 121, 72-84 (2013).

\section{Acknowledgements}

We acknowledge the valuable comments and technical help from Sebastian Amigorena (Institut Curie), Abdelhadi Saoudi (University of Toulouse), Benedict Chambers, John Anderson, Pontus Aspenström, Mari-Anne Hedblad, Sven Petersen, Jakob Michaelsson, Martin Ivarsson (all at Karolinska Institutet), and Eva Severinson (Stockholm University). This work was supported by a PhD fellowship from Fundação para a Ciância e a Tecnologia \#SFRH/BD/47926/2008 and the Queen Silvia foundation to M.A.P.B., a postdoctoral fellowship from the Swedish Cancer Society to M.K., PhD fellowships from Karolinska Institutet to M.O. and C.I.M.D., an amfAR Mathilde Krim Fellowship in Basic Biomedical Research \#108213-51-RKVA to M.N.E.F., grants from Wellcome Trust (104807/Z/14/Z) and by National Institute for Health Research Biomedical Research Centre at Great Ormond Street Hospital for Children NHS Foundation Trust and University College London to A.J.T., as well as the Swedish Research Council, Cancer Society, Childhood Cancer Society, Karolinska Institutet including Center for Allergy Research, the European Commission 7th framework program Marie Curie reintegration grant (\#249177), Åke Olsson foundation, Jeansson foundation, Groschinsky Foundation, Åke Wiberg Foundation, Bergvall Foundation, and the Swedish Medical Society to L.S.W. L.S.W. is a Ragnar Söderberg fellow in Medicine.

\section{Author contributions}

M.A.P.B. and L.S.W. designed research; M.A.P.B., M.K., M.O., K.K.S.S., J.A., C.I.M.D., A.J.W., A.L., I-C.K., R.P.A.W., S.N., L.S.W. performed research; S.B.S., L.E., A.S., M.C.I.K., G.B., S.O.B., M.N.E.F., A.J.T., S.N. contributed with ideas, new reagents and analytic tools; M.A.P.B., M.K., M.O., K.K.S.S., C.I.M.D., S.N., L.S.W. analyzed the data; M.A.P.B. and L.S.W. wrote the manuscripts; and all authors edited the manuscript.

\section{Additional information}

Supplementary Information accompanies this paper at http://www.nature.com/ naturecommunications

Competing financial interests: The authors declare no competing financial interests.

Reprints and permission information is available online at http://npg.nature.com/ reprintsandpermissions/

How to cite this article: Baptista, M. A. P. et al. Deletion of Wiskott-Aldrich syndrome protein triggers Rac2 activity and increased cross-presentation by dendritic cells. Nat. Commun. 7:12175 doi: 10.1038/ncomms12175 (2016).

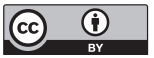

This work is licensed under a Creative Commons Attribution 4.0 International License. The images or other third party material in this article are included in the article's Creative Commons license, unless indicated otherwise in the credit line; if the material is not included under the Creative Commons license, users will need to obtain permission from the license holder to reproduce the material. To view a copy of this license, visit http://creativecommons.org/licenses/by/4.0/

(C) The Author(s) 2016 